\title{
Holocene environmental history recorded in Lake Lyadhej-To sediments, Polar Urals, Russia
}

\author{
Andrei A. Andreev ${ }^{\mathrm{a}, *}$, Pavel E. Tarasov ${ }^{\mathrm{a}, \mathrm{b}}$, Boris P. Ilyashuk ${ }^{\mathrm{c}}$, Elena A. Ilyashuk ${ }^{\mathrm{c}}$, \\ Holger Cremer ${ }^{\mathrm{d}}$, Wolf-Dieter Hermichen ${ }^{\mathrm{a}}$, Frank Wischer ${ }^{\mathrm{a}}$, Hans-Wolfgang Hubberten ${ }^{\mathrm{a}}$ \\ a Alfred Wegener Institute for Polar and Marine Research, Research Unit Potsdam, Telegrafenberg A43, 14473 Potsdam, Germany \\ ${ }^{\mathrm{b}}$ Palaeontology Branch, Institute of Geological Sciences, Free University, Malteserstr. 74-100 Building D, 12249 Berlin, Germany \\ ${ }^{\mathrm{c}}$ Institute of North Industrial Ecology Problems, Kola Science Center, Russian Academy of Sciences, Fersman St. 14, 184200 Apatity, Russia \\ ${ }^{\mathrm{d}}$ Utrecht University, Department of Palaeoecology, Laboratory of Palaeobotany and Palynology, Budapestlaan 4, \\ 3584 CD Utrecht, Netherlands
}

Received 22 October 2004; received in revised form 21 March 2005; accepted 31 March 2005

\begin{abstract}
An 1180 -cm long core recovered from Lake Lyadhej-To $\left(68^{\circ} 15^{\prime} \mathrm{N}, 65^{\circ} 45^{\prime} \mathrm{E}, 150 \mathrm{~m}\right.$ a.s.1.) at the NW rim of the Polar Urals Mountains reflects the Holocene environmental history from ca. 11,000 cal. yr BP. Pollen assemblages from the diamicton (ca. 11,000-10,700 cal. yr BP) are dominated by Pre-Quaternary spores and redeposited Pinaceae pollen, pointing to a high terrestrial input. Turbid and nutrient-poor conditions existed in the lake ca. 10,700-10,550 cal. yr BP. The chironomid-inferred reconstructions suggest that mean July temperature increased rapidly from 10.0 to $11.8{ }^{\circ} \mathrm{C}$ during this period. Sparse, treeless vegetation dominated on the disturbed and denuded soils in the catchment area. A distinct dominance of planktonic diatoms ca. $10,500-8800 \mathrm{cal}$. yr BP points to the lowest lake-ice coverage, the longest growing season and the highest bioproductivity during the lake history. Birch forest with some shrub alder grew around the lake reflecting the warmest climate conditions during the Holocene. Mean July temperature was likely $11-13{ }^{\circ} \mathrm{C}$ and annual precipitation $-400-500 \mathrm{~mm}$. The period ca. 8800-5500 cal. yr BP is characterized by a gradual deterioration of environmental conditions in the lake and lake catchment. The pollen- and chironomid-inferred temperatures reflect a warm period (ca. 6500-6000 cal. BP) with a mean July temperature at least $1-2{ }^{\circ} \mathrm{C}$ higher than today. Birch forests disappeared from the lake vicinity after $6000 \mathrm{cal}$. yr BP. The vegetation in the Lyadhej-To region became similar to the modern one. Shrub (Betula nana, Salix) and herb tundra have dominated the lake catchment since ca. 5500 cal. yr BP. All proxies suggest rather harsh environmental conditions. Diatom assemblages reflect relatively short growing seasons and a longer persistence of lake-ice ca. 5500-2500 cal. yr BP. Pollen-based climate reconstructions suggest significant cooling between ca. 5500 and $3500 \mathrm{cal}$. yr BP with a mean July temperature $8-10{ }^{\circ} \mathrm{C}$ and annual precipitation-300-400 $\mathrm{mm}$. The bioproductivity in the lake remained low after $2500 \mathrm{cal}$. yr BP, but biogeochemical proxies reflect a higher terrestrial influx. Changes in the diatom content may indicate warmer water temperatures and a reduced
\end{abstract}

\footnotetext{
* Corresponding author. Fax: +49 3312882137.

E-mail address: aandreev@awi-potsdam.de (A.A. Andreev).
} 
ice cover on the lake. However, chironomid-based reconstructions reflect a period with minimal temperatures during the lake history.

(C) 2005 Elsevier B.V. All rights reserved.

Keywords: Polar Urals; Holocene; pollen; diatoms; chironomids; biogeochemical records; climate reconstructions

\section{Introduction}

Despite increased palaeoenvironmental studies in the northeast part of the European Arctic over the last decade, relatively little is known about the Holocene environmental changes at the NW rim of the Polar Urals (Fig. 1). Only a few poorly radiocarbon-dated pollen records from nearby regions were published before 1995 (Surova, 1967; Surova et al., 1975; Nikiforova, 1980, 1982; Bolikhovskaya et al., 1988; Veinbergs et al., 1995). Although several new and partly well ${ }^{14} \mathrm{C}$ dated pollen, diatom, macrofossils and insects records from the adjacent regions were published during the last years (Andreev et al., 1998, 2001; Serebryanny et al., 1998; Koshkarova et al., 1999; Andreev and Klimanov, 2000; Kaakinen and Eronen, 2000; Panova and Jankovska, 2000; Oksanen et al., 2001; Väliranta et al., 2001; Kultti et al., 2003; Panova et al., 2003; Paus et al., 2003; Sarmaja-Korjonen et al., 2003), the environmental history of the NW rim of the Polar Urals is still poorly known.

The southward extent of the Barents-Kara Ice Sheet during the Late Pleistocene has been a matter of discussion for a long time. Detailed studies of terrestrial sections recovered in the areas west of the Ural Mountains showed that maximum ice-sheet extension occurred during the Early and Middle Weichselian and that the region was ice-free during the Late Weichselian (e.g., Mangerud et al., 2001). The most recent studies suggest a continental shelf position of the ice-sheet margin during the Last Glacial Maximum (LGM) and, consequently, an ice-free northern mainland including the NW rim of the Polar Urals (e.g., Mangerud et al., 2002; Hubberten et al., 2004 and references therein).

An ESF funded project "Eurasian Ice Sheets" focusing on the Late Pleistocene glacial and climatic history of the Eurasian Arctic was initiated in order to establish a regional chronology of palaeoenvironmen- tal fluctuations since the LGM. A lake-sediment coring was conducted on the Lake Lyadhej-To within this project. The lake is situated at the hypothetical margin of the Middle Weichselian Barents-Kara Ice Sheet (the so-called Halmer Moraine, Mangerud et al., 2001) and was suggested as an excellent long-term archive of environmental changes in the region since the Middle Weichselian. However, the first investigations of the lake cores (Wischer et al., 2001) demonstrated that lake sediments recorded only the Holocene environmental changes. Diatom and preliminary pollen records were published by Cremer et al. (2004). This paper focuses on new environmental and quantitative climatic reconstructions based on radiocarbondated pollen, chironomid, diatom and biogeochemical records from Lake Lyadhej-To. The applied palaeoecological approaches and quantitative climate reconstruction techniques have not been previously combined into a multiproxy study of an anthropogenically not-disturbed lake in the northeast part of the European Arctic.

\section{Study area}

Lake Lyadhej-To is situated at the NW rim of the Polar Urals $\left(68^{\circ} 15^{\prime} \mathrm{N}, 65^{\circ} 45^{\prime} \mathrm{E}, 150 \mathrm{~m}\right.$ a.s.l., Fig. 1a). Numerous small and shallow thermokarst/glaciokarst lakes surround the lake, which is ca. $2.5 \mathrm{~km}$ long and $1.5 \mathrm{~km}$ wide with a maximum depth of $26 \mathrm{~m}$ (Fig. 1b). A hummocky landscape around the lake was probably formed during the disintegration of the ice sheet. Laminated fine sands in kame sediments nearby the lake were OSL dated to $90 \mathrm{ka}$ (Henriksen et al., 2003). Potentially, the lake is well situated for archiving continuous sedimentary records since the last glaciation. Geomorphological evidence for a presumably Early- to Middle Weichselian Barents-Kara Ice Sheet margin was found ca. $25 \mathrm{~km}$ to the south of the studied lake (Astakhov et al., 1999). 

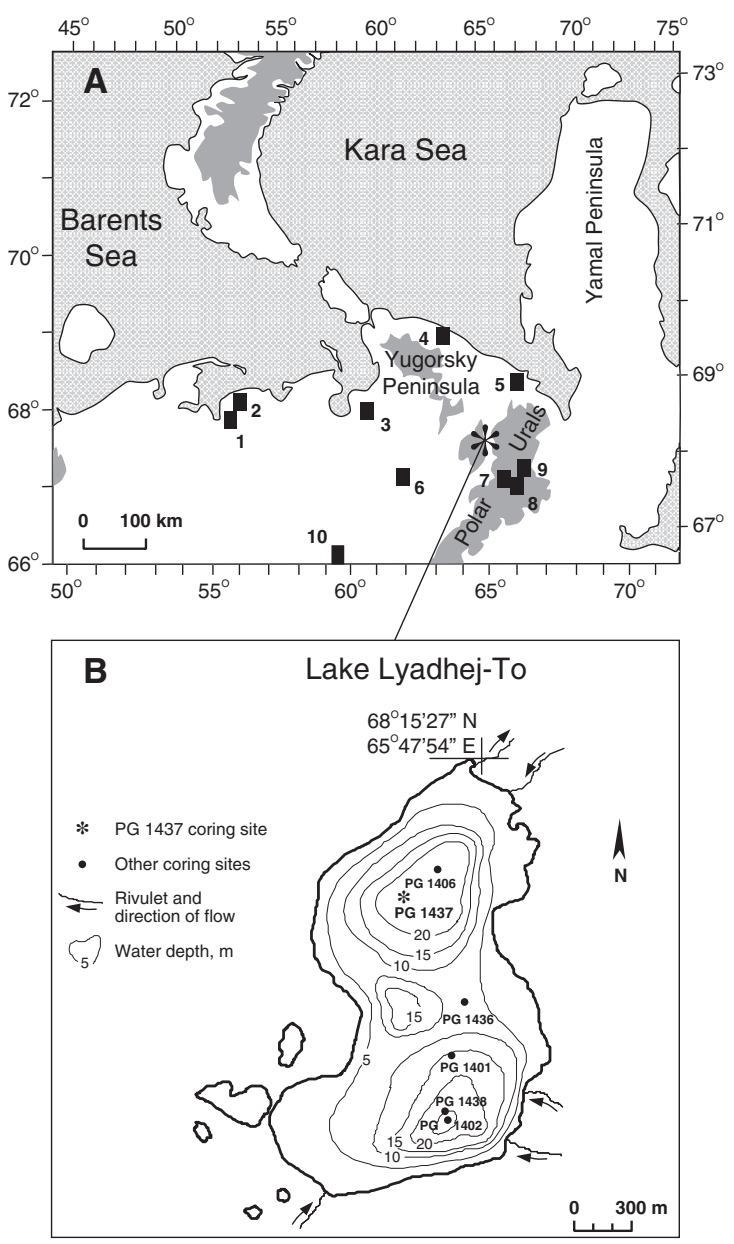

Fig. 1. (A) Map of the southern Kara Sea and Bolshezemelskaya Tundra region, showing the location of Lake Lyadhej-To. Light shading depicts elevations of 100-200 m, and dark grey shading shows elevations $>200 \mathrm{~m}$. *-this study. The previously studied sections are: 1-Veinbergs et al., (1995); 2-Kaakinen and Eronen (2000), Väliranta et al. (2001); 3-Bolikhovskaya et al. (1988), Andreev and Klimanov (2000); 4-Andreev et al. (2001); 5Andreev et al. (1998), Serebryanny et al. (1998); 6-Oksanen et al. (2001); 7-Surova (1967), Surova et al. (1975); 8-Panova and Jankovska (2000), Panova et al. (2003); 9-Koshkarova et al. (1999); 10 - Kultti et al. (2003). (B) Bathymetry and coring sites in the Lake Lyadhej-To area.

The modern lake consists of a southern and a northern basin, which are up to 26 and $21 \mathrm{~m}$ deep, respectively. Main inflows are three rivulets in the south, whereas a minor inflow and outflow are situated in the north of the lake (Fig. 1b). The lake has a shallow littoral zone. Only in the south is there a steep slope with a height of approximately $15 \mathrm{~m}$ (Hermichen et al., 2000).

Mean July temperature $\left(T_{\mathrm{VII}}\right)$ in the area is about $8{ }^{\circ} \mathrm{C}$, mean January temperature is about -20 to -22 ${ }^{\circ} \mathrm{C}$, and mean annual temperature is about $-10{ }^{\circ} \mathrm{C}$. The total annual precipitation is about $400-600 \mathrm{~mm}$, with $50 \%$ of the precipitation occurring during the summer (Atlas Arktiki, 1985). Lake Lyadhej-To is situated within shrub-herb tundra. Shrubs and semishrubs such as Betula nana, Salix phylicifolia, $S$. lapponicum, S. lanata, S. glauca, Vaccinium vitisidaea, V. uliginosum, Ledum palustre, Empetrum hermaphroditum, Rubus chamaemorus, Dryas octopetala, herbs such as Alopecurus alpinus, Poa abbreviata, Oxyria digyna, Carex stans, C. rotundifolia, Eriophorum medium, and mosses such as Aulacomnium turgidum, Drepanocladus uniciatus, Calliergon sarmentosum and Hylocomium splendens dominate the vegetation. Soils in the area are tundra-gley and peaty-gley (histosols and inceptisols) with an activelayer thickness of ca. 40-50 cm (Atlas Arktiki, 1985).

\section{Methods}

Coring of the lake sediments was performed from 1.9 m thick ice in April 1999 using a tripod with hand-operated winches (Hermichen et al., 2000). Sediment coring was conducted at three locations PG1436, PG1437 and PG1438 (Fig. 1b). A light gravity corer was applied for the sampling of soft near-surface sediments (maximum core length of 55 $\mathrm{cm})$. Longer sediment cores were obtained with a piston corer. A manually operated hammer $(20 \mathrm{~kg})$ helped the penetration of the corer. A detailed description of the coring technique is given by Melles et al. (1994). Material from the longest $1180 \mathrm{~cm}$ sediment core, PG 1437, collected from the northern basin, was used for the pollen, diatom and chironomid studies. Samples for radiocarbon dating were taken from the PG 1437 core in ca. $100 \mathrm{~cm}$ intervals. A total of 14 radiocarbon AMS dates on picked non-identified macrofossils and 6 dates on dispersed organic carbon in bulk till samples were measured in Leibniz Laboratory, Kiel (Table 1).

The total organic carbon content (TOC) was measured with a Metalyt-CS-1000-S apparatus (ELTRA Corp.), whereas the total sulphur (TS) and total carbon 
Table 1

Radiocarbon ages $\left({ }^{14} \mathrm{C}\right.$ yr BP) are calibrated into calendar years (cal. yr BP)

\begin{tabular}{|c|c|c|c|c|c|}
\hline & Depth, cm (Drive No) & Dated material & ${ }^{14} \mathrm{C}$ ages, yr BP & Calibrated ages, cal. yr BP & Laboratory No KIA. . \\
\hline 1 & $9(1437-1)$ & Non-identified macrofossils & $690 \pm 30$ & $620 \pm 55$ & 10,040 \\
\hline 2 & $99(1437-2)$ & Non-identified macrofossils & $2460 \pm 40$ & $2550 \pm 200$ & 8915 \\
\hline 3 & $201(1437-2)$ & Non-identified macrofossils & $5135 \pm 60$ & $5870 \pm 125$ & 10,041 \\
\hline 4 & $299(1437-3)$ & Non-identified macrofossils & $6730 \pm 70$ & $7580 \pm 105$ & 8916 \\
\hline 5 & $399(1437-3)$ & Non-identified macrofossils & $8550 \pm 100$ & $9520 \pm 190$ & 8920 \\
\hline 6 & $501(1437-4)$ & Non-identified macrofossils & $9230 \pm 90$ & $10,450 \pm 230$ & 8917 \\
\hline 7 & $597(1437-4)$ & Non-identified macrofossils & $10,780 \pm 140 *$ & $12,750 \pm 390 *$ & 12,131 \\
\hline 8 & $653(1437-4)$ & Non-identified macrofossils & $11,230 \pm 150^{*}$ & $13,340 \pm 450^{*}$ & 8759 \\
\hline 9 & $671(1437-4)$ & Non-identified macrofossils & $14,210 \pm 90^{*}$ & $17,060 \pm 510^{*}$ & 8760 \\
\hline 10 & $718(1437-5)$ & Shrub twig & $9600 \pm 60^{*}$ & $10,940 \pm 235^{*}$ & 8761 \\
\hline 11 & $735(1437-5)$ & Non-identified macrofossils & $10,940 \pm 90^{*}$ & $12,910 \pm 255^{*}$ & 12,132 \\
\hline 12 & $794(1437-5)$ & Non-identified macrofossils & $11,850 \pm 80^{*}$ & $14,370 \pm 865^{*}$ & 12,133 \\
\hline 13 & $795(1437-5)$ & Total organic carbon & $32,310 \pm 500^{*}$ & & 12,776 \\
\hline 14 & $911(1437-5)$ & Total organic carbon & $36,060 \pm 800^{*}$ & & 12,780 \\
\hline 15 & $994(1437-5)$ & Non-identified macrofossils & $9880 \pm 50 *$ & $11,370 \pm 180 *$ & 12,134 \\
\hline 16 & $995(1437-6)$ & Total organic carbon & $27,260 \pm 270 *$ & & 12,777 \\
\hline 17 & $1035(1437-6)$ & Moss remains & $9490 \pm 60$ & $10,830 \pm 265$ & 12,135 \\
\hline 18 & $1147(1437-6)$ & Total organic carbon & $38,690 \pm 270^{*}$ & & 12,778 \\
\hline 19 & $1151(1437-6)$ & Total organic carbon & $38,920 \pm 630^{*}$ & & 12,136 \\
\hline 20 & $1155(1437-6)$ & Total organic carbon & $34,190 \pm 570 *$ & & 12,779 \\
\hline 21 & $11(1438-1)$ & Non-identified macrofossils & $710 \pm 30$ & $630 \pm 60$ & 12,137 \\
\hline 22 & $101(1438-1)$ & Non-identified macrofossils & $3112 \pm 40$ & $3330 \pm 114$ & 10,043 \\
\hline 23 & $201(1438-1)$ & Non-identified macrofossils & $3660 \pm 60$ & $3970 \pm 185$ & 10,044 \\
\hline 24 & $301(1438-2)$ & Non-identified macrofossils & $7160 \pm 230$ & $7990 \pm 410$ & 10,045 \\
\hline 25 & $399(1438-2)$ & Non-identified macrofossils & $8760 \pm 70$ & $9850 \pm 300$ & 10,046 \\
\hline 26 & $501(1438-2)$ & Non-identified macrofossils & $9820 \pm 150 *$ & $11,240 \pm 100$ & 8925 \\
\hline 27 & $633(1438-3)$ & Non-identified macrofossils & $12,430 \pm 70 *$ & $9820 \pm 150$ & 12,138 \\
\hline 28 & $759(1438-3)$ & Non-identified macrofossils & $20,260 \pm 280^{*}$ & & 12,139 \\
\hline 29 & $844(1438-4)$ & Non-identified macrofossils & $12,370 \pm 570 *$ & $14,810 \pm 690$ & 12,140 \\
\hline 30 & $921(1438-4)$ & Non-identified macrofossils & $9725 \pm 50$ & $11,060 \pm 170$ & 12,141 \\
\hline 31 & $28(1401-1)$ & Total organic carbon & $4090 \pm 50$ & & 6629 \\
\hline 32 & $41(1401-1)$ & Total organic carbon & $5750 \pm 40$ & & 6630 \\
\hline 33 & $18(1402-1)$ & Total organic carbon & $3370 \pm 40^{*}$ & & 6631 \\
\hline 34 & $41(1402-1)$ & Total organic carbon & $2990 \pm 40$ & & 6632 \\
\hline 35 & $35(1406-1)$ & Total organic carbon & $5250 \pm 40$ & & 6633 \\
\hline
\end{tabular}

Used calibration method: CALIB 4.3, Method I, intercept ages, errors at $2 \sigma$ probability (Stuiver et al., 1998). Ages assumed as "too old" are marked with *.

(TC) contents were analyzed with a CHNS-932 determinator (LECO Corp.). The calcium carbonate $\left(\mathrm{CaCO}_{3}\right)$ percentages were calculated based on the carbonate content (difference between TC and TOC) and the atomic weights of the elements.

A standard HF technique was used for pollen preparation (Berglund and Ralska-Jasiveczowa, 1986). At least 200 pollen grains were counted in every sample. The identification of pollen was mainly based on Kupriyanova and Aleshina (1972, 1978), Punt et al. (1988, 1995, 2003), Punt and Blackmore (1995) and Reille (1992, 1995, 1998). The relative frequency of arboreal and non-arboreal pollen taxa was calculated based on the sum of terrestrial pollen taxa. Calculation of spore percentages was based on the sum of pollen and spores. We assumed that Tertiary spores and indeterminable, poor-preserved and mineralized Pinaceae are obviously redeposited taxa. Their relative abundances were based on the sum of pollen and redeposited taxa. The percentage of algae was based on the sum of pollen and algae.

Diatom slides were prepared using $0.2-1.5 \mathrm{~g}$ of freeze-dried bulk sediment that was treated subsequently with hydrogen peroxide, hydrochloric acid 
and nitric acid in order to remove all organic and carbonate components (Cremer et al., 2001). Slides were prepared using the sedimentation tray method described by Battarbee (1973), and the high refraction mounting medium Naphrax ${ }^{\circledR}$ was used to mount the cover-glasses on slides. Generally, a minimum of 500 diatom valves was counted. The identification of diatom species was mainly based on Krammer and Lange-Bertalot (1991, 1999a,b, 2000). For details concerning the applied diatom taxonomy, see also Cremer et al. (2004).

Chironomid analysis was carried out on 60 samples, with roughly $10 \mathrm{~cm}$ sampling intervals. Because the chironomid head capsules could be easily be destroyed by KOH treatment (Walker, 2001), the sediments were neither $\mathrm{KOH}$-treated nor sieved prior to sorting. The sediments of each sample were sorted in a Bogorov counting tray under a dissecting microscope (magnification $\times 25$ ). Chironomid remains were picked out and mounted on glass slides in glycerol for microscopic identification. Whole chironomid head capsules and fragments containing greater than half of the mentum were counted as one head capsule. Split fragments of chironomid head capsules that included half the mentum were common among Orthocladiinae. These fragments were counted as one half. At least 50 chironomid head capsules were counted and identified in each sample. Several studies have demonstrated that this sample size provides representative counts for environmental inference analyses (Heiri and Lotter, 2001; Larocque, 2001; Quinlan and Smol, 2001).

Identifications of the chironomid head capsules were primarily based on Wiederholm (1983). Identifications of the chironomid remains to a more precise taxonomic level were carried out using the descriptions for some genera (viz., Hofmann (1971) for Chironomus; Sæther (1975) for Heterotrissocladius; Wiederholm (1983) for Corynocera, Microtendipes, and Psectrocladius; Makarchenko and Makarchenko (1999) for Corynoneura and Parakiefferiella). The chironomid head capsules of Corynocera and Tanytarsus with a surface tooth forming a large plate on the mandible were identified as Corynocera oliveritype when the mandibles were present. Otherwise, they were grouped as Tanytarsus indet. Micropsectra radialis-type and Micropsectra insignilobus-type were separated based on the presence of a short antennal pedestal and a strongly reduced post-occipital plate associated with the M. radialis-type specimens (Heiri et al., 2004). Two different Sergentia taxa were identified using the descriptions in Pankratova (1983) and Makarchenko and Makarchenko (1999): Sergentia coracina-type with only two apical teeth on the premandible, and Sergentia longiventristype with two apical and two inner accessory teeth on the premandible. Most chironomid taxa could be identified to the generic or specific level, but in some cases, a larger taxonomic grouping was necessary (e.g., Cricotopus/Orthocladius, Heterotrissocladius brundini/ H. maeaeri, Limnophyes/Paralimnophyes). Zones were delimited by significant changes in chironomid assemblages using visual inspection.

The Tilia/TiliaGraph software (Grimm, 1991) was used for the calculation of percentages and for drawing of the diagrams.

The best modern analogue (BMA) method (Guiot, 1990) has been used to reconstruct climate from the pollen record. The method uses a chord distance to determine the similarity between each analyzed pollen spectrum and each spectrum in the modern pollen data-set. PPPBase software (Guiot and Goeury, 1996) facilitates calculations and selection of the best analogues. In the present study, the BMA approach has been used with the modern pollen data-set including 1110 surface pollen spectra from northern Eurasia (Andreev et al., 2003, 2004). These data mainly came from the compilation of Tarasov et al. (1998). For the present study, we also compiled more than 200 additional spectra from the Russian Arctic (Bolikhovskaya and Bolikhovskii, 1994; Edwards et al., 2000; Lozhkin et al., 2001; Pisaric et al., 2001; Solovieva et al., 2005 in press). A total of 77 arboreal and non-arboreal pollen taxa were included in the analysis. Modern climate variables at the sampling sites have been calculated from the updated version of the Leemans and Cramer (1991) climate database (W. Cramer, pers. com.).

The quality of the analogues is measured by the chord distance, i.e. the Euclidean distance of the logarithmically transformed taxa percentages. The ten modern spectra most similar to each fossil spectrum were selected as the best analogues. This number is chosen experimentally (Tarasov et al., 2002). All reconstructed climate variables are estimated from the present climate corresponding to those modern spectra 
and each climatic parameter is expressed as the mean weighted value of the ten values that are selected as analogues for the fossil spectra. An analogue spectrum with the greatest similarity to a given fossil spectrum has greater impact on the mean value calculation (Guiot and Goeury, 1996). The lower and the upper deviations are defined by the min and max values of the farthest analogues, respectively.

The quantitative transfer function developed from a 100-lakes calibration data-set in northern Sweden (Larocque et al., 2001) was applied to the chironomid record from Lake Lyadhej-To to develop a quantitative estimate of $T_{\mathrm{VII}}$ changes during the Holocene. In addition, some taxonomic revisions in the function were applied (e.g., Constempellina brevicosta should be replaced by Stempellinella/Zavrelia; E. Grahn, pers. com.). The function was developed using weighted averaging partial least squares (WA-PLS) regression (ter Braak and Juggins, 1993) with two components. The transfer function yielded a root mean square error of prediction (RMSEP, jack-knifed) of $1.13{ }^{\circ} \mathrm{C}$, a coefficient of determination $\left(r^{2}\right.$, jack-knifed) of 0.65 , and mean and maximum bias of 0.025 and $2.1{ }^{\circ} \mathrm{C}$, respectively (see Larocque et al., 2001, for more details).

As a result of the different taxonomic resolution between the modern calibration set and the fossil assemblages, the taxonomy of the fossil assemblages was harmonized with the modern calibration sets before the $T_{\mathrm{VII}}$ reconstruction (e.g., Ablabesmyia and other Pentaneurini were treated as Pentaneurini indet.; Parakiefferiella bathophila-type and Parakiefferiella triquetra (Pankratova, 1970) as Parakiefferiella bathophila-type). After taxonomic harmonization, the fossil data were screened first by excluding all taxa that did not have at least two occurrences with a minimum relative abundance of $2 \%$.

The program WAPLS 1.51 (S. Juggins and C.J.F. ter Braak, unpublished program) was used to perform the $T_{\mathrm{VII}}$ reconstructions based on the fossil chironomid assemblages and to calculate sample-specific prediction errors (SSPE). SSPE values were estimated by Monte Carlo simulation (500 runs) following Birks (1995). To stabilize variances among taxa, percentage data were transformed using the natural logarithm $(\ln [x+1])$ prior to reconstructions.

Although, chironomids have been used to develop models for reconstructing air temperatures in NW Europe (e.g., Lotter et al., 1997; Olander et al.,
1999; Brooks and Birks, 2000; Larocque et al., 2001), there is no the chironomid training set for NE Europe yet. However, the model developed by Larocque et al. (2001) for northern Sweden have been chosen for our study because it have been developed for a climatically rather similar region and the chironomid fauna used in the Sweden calibration set is also quite similar to the Lake Lyadhej-To one. This model has already been used for temperature reconstructions in northern regions of Russia such as the Laptev Sea region (Andreev et al., 2004) and the Kola Peninsula (Ilyashuk et al., 2005 in press) and we have found that the chironomid-inferred $T_{\mathrm{VII}}$ values are comparable with temperatures inferred from other palaeoecological proxies. Two reconstruction diagnostic statistics were calculated to evaluate the potential reliability of the chironomid-inferred $T_{\mathrm{VII}}$ reconstructions. First, the percentage of the fossil assemblages consisting of chironomid taxa absent from the modern calibration set was used to estimate how well each fossil assemblage is represented in the modern calibration set (Birks, 1998). Second, goodness-of-fit measures derived from a canonical correspondence analysis (CCA) of the modern and fossil data with the environmental variable of interest (e.g., $\left.T_{\mathrm{VII}}\right)$ as the sole constraining variable were used to assess the fit of the fossil assemblages to the environmental variable of interest (Birks et al., 1990). CCA was accomplished using the program CANOCO for Windows version 4.0 (ter Braak and Šmilauer, 1998). The reliability of the chironomid-inferred $T_{\mathrm{VII}}$ values was assessed by comparing the squared residual distances of fossil assemblages to $T_{\mathrm{VII}}$, when run as passive samples in a CCA of the modern calibration assemblages constrained to $T_{\mathrm{VII}}$. Fossil samples with a low squared residual distance from the $T_{\mathrm{VII}}$ axis have a 'good' fit to $T_{\mathrm{VII}}$. According to Birks et al. (1990) any fossil samples with a squared residual distance equal to, or larger than, the squared residual distance of the extreme $10 \%$ or $5 \%$ of the modern calibration set samples are considered to have a 'poor' or 'very poor' fit, respectively, to $T_{\mathrm{VII}}$. However, following Bigler et al. (2002), the criterion of 'fit' was used as a guide to whether fossil assemblages contain abundances of taxa with relatively weak or strong relationships to the variable being reconstructed, since fossil assemblages with a poor 'fit' may provide accurate estimates of an environmental variable, and assem- 
blages with good 'fit' may not always provide accurate estimates.

A locally weighted regression smoothing (LOESS; Cleveland et al., 1993) with a span of 0.15 was used to help to visualize the major trend in the quantitative reconstructions.

\section{Results and interpretations}

\subsection{Lithostratigraphy}

The basal $488 \mathrm{~cm}$ of the PG 1437 core are composed of highly consolidated greyish diamicton with gravel, separated by a thin silty peat interlayer at the 1038-1030 cm depth (Fig. 2). Rare plant remains occur in the upper diamicton layer (1030-697 cm). The diamicton is overlain by stratified to laminated clayey gyttja. Grain size distribution (Fig. 2) in the basal $50 \mathrm{~cm}$ of the limnic strata $(697-643 \mathrm{~cm})$ reflects a high terrigenous input (up to $2 \%$ of sand), whereas the lithology of the overlying strata points to low sedimentation rates. The black-coloured clayish gyttja $(643-149 \mathrm{~cm})$ contains almost no sand. The upper 149 $\mathrm{cm}$ of the profile consist of dark-brown to black silty gyttja with some sandy bands (up to $1.2 \mathrm{~cm}$ thick). A higher amount of coarse-grained sand in the uppermost metre was caused by an increase of terrigenous input.

To determine the source area of the diamicton/ flow till in the lake, its geochemical signatures were compared with till reference. Geochemical and chronological analyses on this core undoubtedly showed that the basal till originated from Weichselian Barents-Kara Ice Sheet samples (Wischer et al., 2001).

\subsection{Chronology}

In total, 20 samples from the core PG 1437 were ${ }^{14} \mathrm{C}$ dated (Table 1, Fig. 2). Although the plant remains were expected to provide reliable dates, the ages from the consolidated diamicton are not in a chronological order. This reflects the reworked character of the dated material which is obviously too old compared to the age of the thin peat layer and the age of the plant remains from $9.94 \mathrm{~m}$ depth. We believe that the youngest date is the most reliable, as there is no evidence of possible contamination of the peat by younger organic material.

The ${ }^{14} \mathrm{C}$ ages from the transition zone between the diamicton and the clayey gyttja (ca. 800-600 cm) reflect a high terrigenous input and point to the reworked character of the dated material. Therefore, they were not used for the core chronology. However, these dates reflect a very high accumulation rate during the initial phase of the lake basin formation between ca. 10,900 and 10,700 cal. yr BP. The sedimentation of allochthonous material started about 10,700 cal. yr BP. After ca. 10,550 cal. yr BP, sedimentation slowed and stabilized according to the core chronology (Fig. 2).

The ${ }^{14} \mathrm{C}$ ages obtained from the PG 1438 core (southern basin) are very similar to the PG 1437 ages from similar depths (Table 1) that point to similar lake development stages in both basins. The ages from the short cores (PG 1401, PG 1402 and PG 1406) collected in the small shallow lakes in the Lake Lyadhej-To vicinity show that sedimentation rate in these small lakes during the late Holocene was ca. 3-4 times slower than in Lake Lyadhej-To (Table 1).

\subsection{Biogeochemical records}

The total organic carbon (TOC), $\delta{ }^{13} \mathrm{C}_{\mathrm{org}}, \mathrm{N}$, and $\mathrm{S}$ contents were estimated for the core (Fig. 3). The lacustrine sediments can be subdivided into five biogeochemical units. Unit 1 , the initial stage of the lake (ca. 700-645 cm) is characterized by high amounts of terrigenous input. The low $\mathrm{TOC} / \mathrm{N}$ ratios point to input of minerogenous nitrogen. $\delta^{13} \mathrm{C}_{\mathrm{org}}$ values have a narrow range, around $-26 \%$. This is similar to $\delta^{13} \mathrm{C}_{\text {org }}$ values $(-26.6 \%$ to $-24.3 \%$ ) from terrestrial plant material from the Arctic Siberia (Gundelwein, 1998). In contrast, fresh-water plankton generally has depleted $\delta{ }^{13} \mathrm{C}_{\text {org }}$ values of $-30 \pm 3 \%$ (Ariztegui and McKenzie, 1995). Thus, $\delta^{13} \mathrm{C}_{\text {org }}$ values indicate a high input of terrestrial plant remains. The bioproductivity in this initial lake was very low.

Unit $2(645-295 \mathrm{~cm})$ consists of lake sediments with the highest TOC, $\mathrm{N}$ and $\mathrm{S}$ contents, reflecting the period that the lake shows maximum bioproduction. Light $\delta^{13} \mathrm{C}_{\text {org }}$ values also point to a lacustrine source (phytoplankton) of the organic matter and suggest rather high lake bioproductivity. 


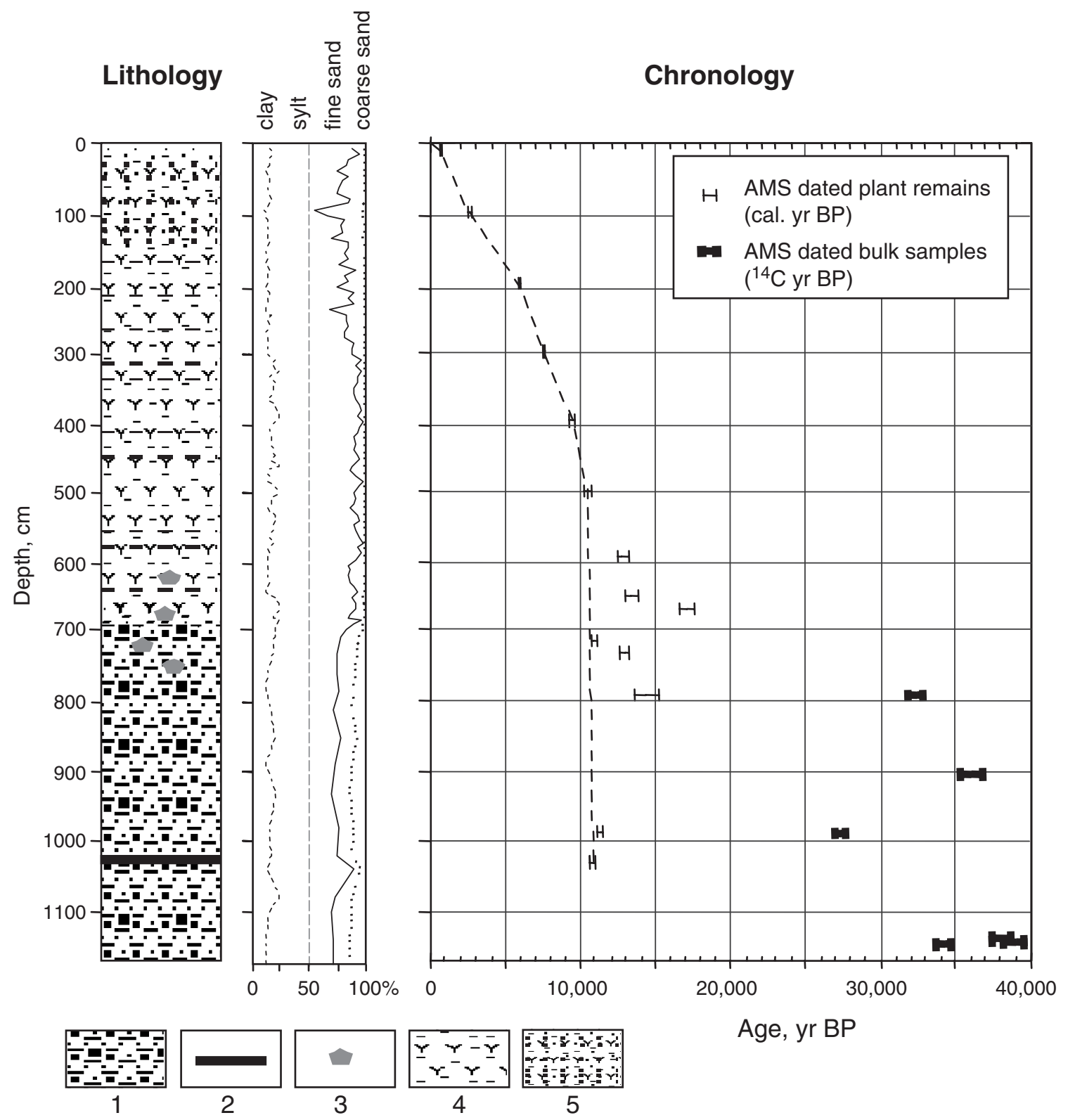

Fig. 2. Lithology and chronology of the 1437 core. 1-diamicton, 2-peat lens, 3-plant remains, 4-laminated clayey gyttja. 5-stratified silty gyttja.

The sediments from Unit $3(295-220 \mathrm{~cm})$ are characterized by decreases in TOC, $\mathrm{N}$ and $\mathrm{S}$ values, that together with a gradual increase of $\delta^{13} \mathrm{C}_{\text {org }}$ values and a decrease in carbonate content to almost zero point to a decrease of bioproductivity in the lake.

Low TOC, $\mathrm{N}$ and $\mathrm{S}$ contents and the absence of authigenic carbonate in the sediments of Unit 4
$(220-90 \mathrm{~cm})$ and Unit $5(90-0 \mathrm{~cm})$ reflect low bioproductivity and deteriorating conditions in the lake. Fluctuating $\mathrm{TOC} / \mathrm{TN}$ ratios in Unit 5 and high contents of $\delta{ }^{13} \mathrm{C}_{\text {org }}$ show that the terrestrial organic matter supply during the sedimentation of Unit 5 was slightly higher than during the sedimentation of Unit 4. 


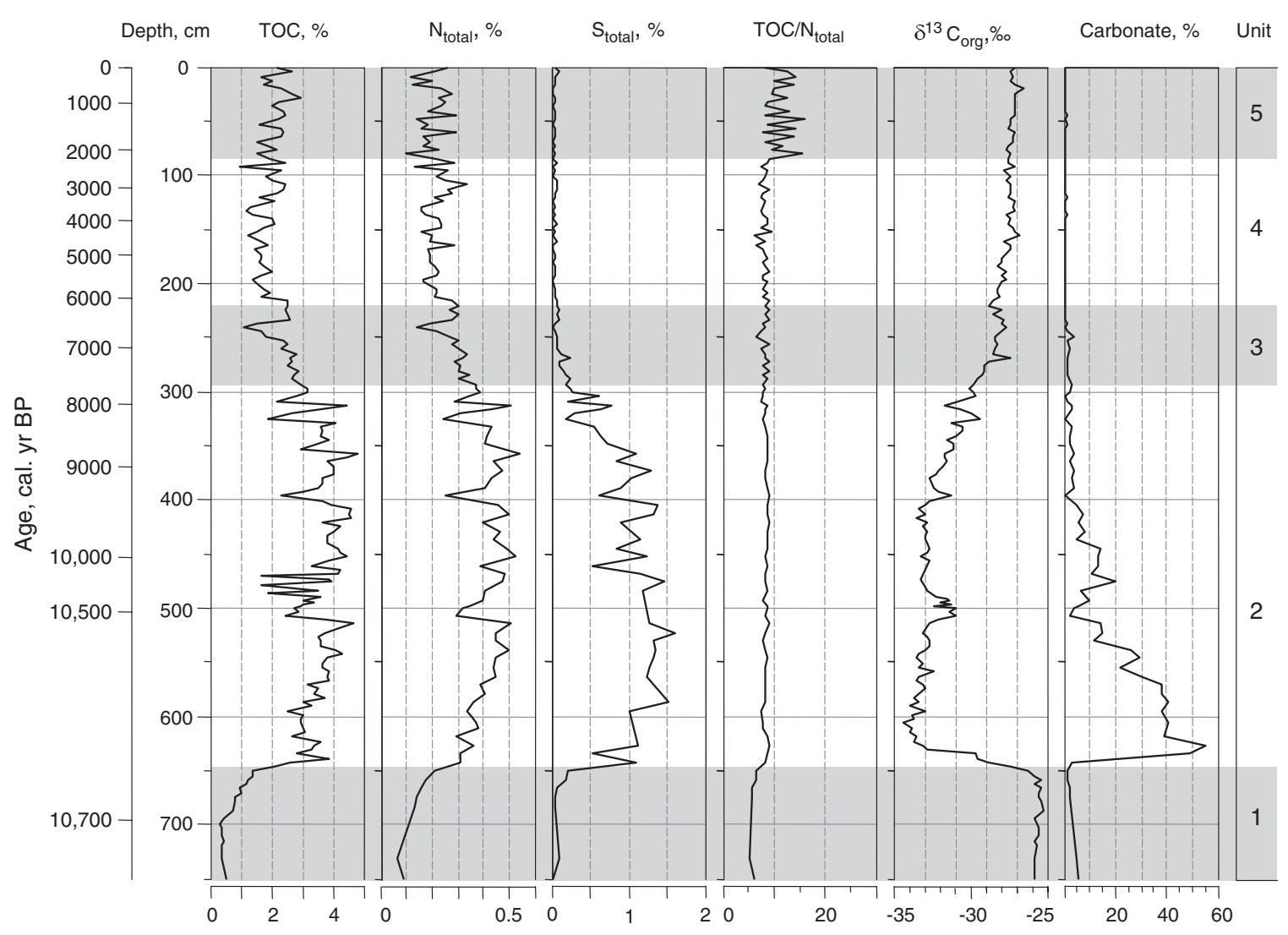

Fig. 3. Selected geochemical parameters from the core.

\subsection{Pollen}

The reworked flow till sediments contain few pollen grains, mostly reworked Pre-Quaternary spores and badly preserved indeterminable coniferous pollen. Equisetum spores and Cyperaceae pollen dominate in the peat layer (1034-1035 cm depth).

Generally, the lake sediments are rich in pollen and palynomorphs (Fig. 4). However, the sediments at the 700-650 cm depth (pollen zone I, PZ-I) have a very low pollen concentration and contain numerous indeterminable coniferous pollen. The rare Cyperaceae, Poaceae, and Betula sect. Nanae pollen suggest sparse, treeless vegetation. Large amounts of Equisetum spores, pollen of Cichoriaceae, Artemisia and the presence of Encalypta spores point to disturbed and denuded soils in the catchment area. The upper 650 $\mathrm{cm}$ of the lake sediments contain numerous wellpreserved pollen and spores and have a high pollen concentration. The pollen concentration is highest in PZ-II (650-500 cm). Redeposited coniferous pollen almost disappears from the pollen spectra at the bottom of this zone. Pollen of Betula (especially sect. Albae) dominated. Alnus fruticosa has a maximum in this zone. PZ-III $(500-375 \mathrm{~cm})$ is characterized by large amounts of Betula pollen and a gradual increase of long-distance transported Picea obovata. Total pollen concentration significantly decreases in this zone. PZ-IV $(375-205 \mathrm{~cm})$ is notable for an increase in Betula sect. Nanae, Cyperaceae and a further increase of long-distance transported coniferous (Pinus sylvestris, P. sibirica and Picea obovata) pollen contents, while Betula sect. Albae pollen percentages and total pollen concentration are reduced. PZ-V $(205-0 \mathrm{~cm})$ is characterized by a further increase of Cyperaceae, Poaceae and other herbs. Pollen of typical tundra taxa (Ericales, Polygonum viviparum, Epilobium, Polemonium) have 


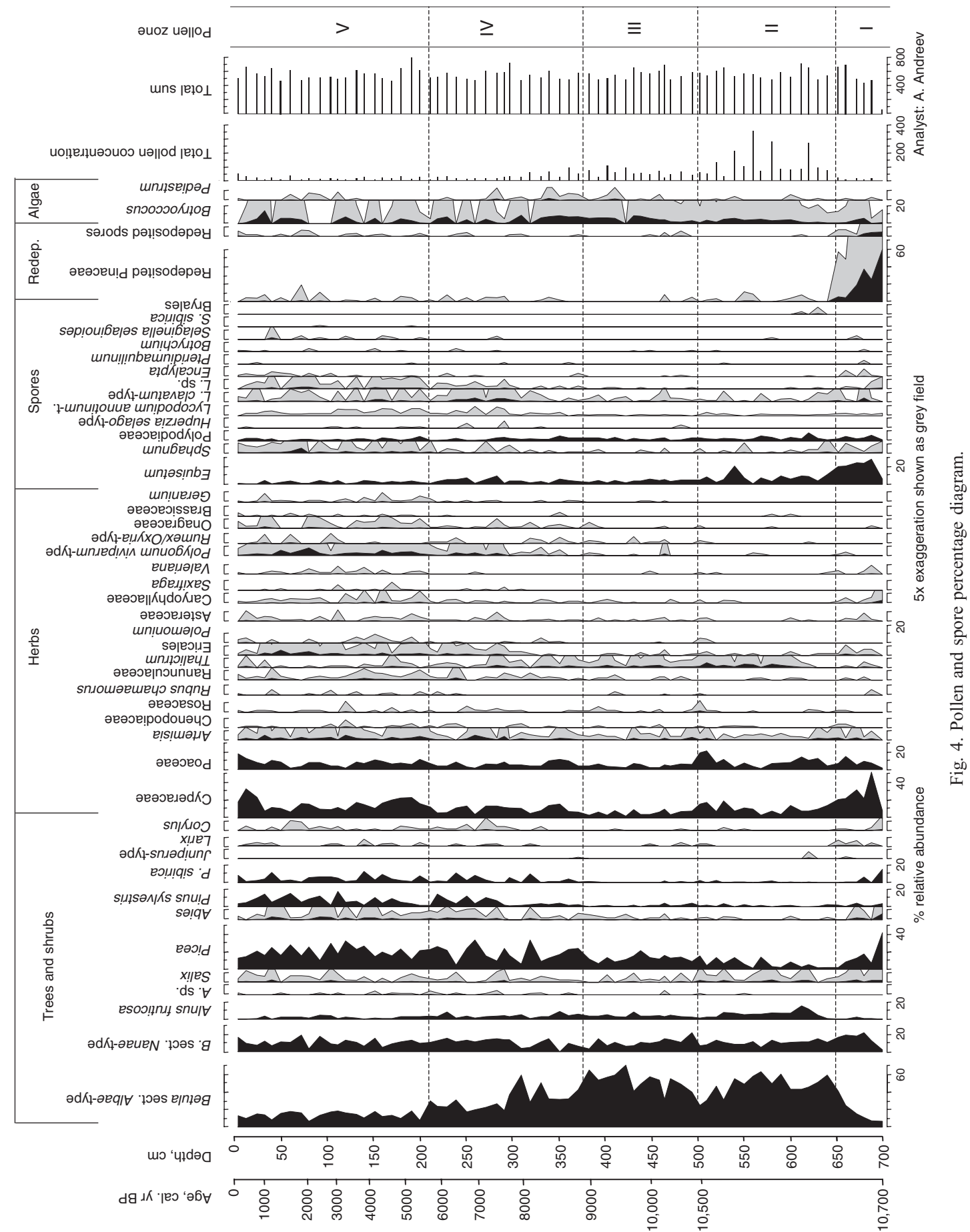


maxima in this zone, while total pollen concentration is the lowest here.

\subsection{Diatoms}

A total of 153 diatom taxa from 42 genera were identified in the core (Cremer et al., 2004). Achnanthes (20 taxa), Fragilaria (17 taxa, including Pseudostaurosira, Staurosira and Staurosirella) and Navicula (19 taxa) are the most diverse genera. Diatom assemblages, however, are generally dominated by a few plankton species belonging to the genera Aulacoseira and Stephanodiscus and by small Staurosira and Staurosirella species. The diatom diagram (Fig. 5) is visually subdivided into seven biostratigraphical units, which are briefly described in chronological order.

Unit A $(669-646 \mathrm{~cm})$ is characterized by the presence of Paralia siberica, a taxon that is known only from Paleocene and Eocene deposits. Its occurrence indicates a relatively high input of redeposited material into the lake basin. The nearly complete absence of autochthonous plankton diatoms at the same time shows that there was no significant pelagic bioproductivity in the lake.

Unit B (646-396 cm) shows the highest diatom valve concentrations $\left(2-5 \times 10^{9}\right.$ valves per gram sediment) and is dominated by Stephanodiscus taxa ( $S$. hantzschii, S. minutulus, S. parvus). Three other species, Aulacoseira islandica, Staurosira construens and Staurosirella pinnata are of minor importance. Towards the end of Unit B, the significance of these species gradually decreases, whereas the relative abundance of $A$. islandica increases.

The diatom assemblage of Unit C (396-345 cm) consists mainly of $A$. islandica, Staurosira construens, Staurosirella pinnata and the Stephanodiscus group. Compared to the previous unit, the latter group occurs with distinctly lower relative abundances. The unit has also the highest concentration of Cyclotella ocellata in the whole sequence. The total diatom abundance is lower than $2 \times 10^{9}$ valves per gram of freeze-dried sediment.

Unit D $(345-260 \mathrm{~cm})$ is characterized by a further decrease of total diatom concentration and the contents of Stephanodiscus group. The dominating diatom species in the unit is Aulacoseira subarctica, whereas $S$. construens and $S$. pinnata are of secondary importance. Achnanthes spp. gradually increase in relative abundance in this unit.

Unit E (260-93 cm) represents the longest period of relative stability in terms of the composition of the diatom community. The diatom assemblage is dominated by the periphytic species $S$. construens and $S$. pinnata, and Achnanthes spp. Planktic diatoms generally play a minor role in this unit. The total diatom abundance has lowest values in this unit (below $1 \times 10^{9}$ valves per gram sediment).

A. subarctica dominates Unit F $(93-0 \quad \mathrm{~cm})$, whereas the abundances of $S$. construens, $S$. pinnata and Achnanthes spp. are slightly reduced. The abundance of Cyclotella tripartita increases in the upper part of the unit. The total diatom valve concentration is slightly higher than in the previous unit. Diatom assemblages of the uppermost sediments (ca. 350-0 cal. yr BP) are similar to the Unit E ones: planktic diatoms are of minor importance and $S$. construens, $S$. pinnata and Achnanthes spp. dominate.

\subsection{Chironomids}

In total, 59 chironomid taxa were identified in the core. Three distinct assemblage zones: CZ-I, CZ-II, and CZ-III, were distinguished based on the changes in the chironomid stratigraphy (Fig. 6). The first chironomid zone (CZ-I; 696-649 cm) corresponds to the initial phase of the lake basin formation. The lowest concentration of chironomid head capsules (3-8 capsules $\mathrm{g}^{-1}$ ) characterizes this zone. It is worthy of note that Ceratopogonidae (Dasyheleatype) head capsules were found only in the deepest sample (694-696 cm). CZ-1 is dominated by Heterotrissocladius subpilosus, H. brundini/H. maeaeri, and Abiskomyia. All these taxa have been established as cold-temperature indicators (Olander et al., 1999; Korhola et al., 2000; Larocque et al., 2001). Near the top of this zone, Micropsectra insignilobus-type increases up to $12 \%$ and Sergentia coracina-type up to $24 \%$. Both taxa are characterized by a broader range of thermal tolerance (Olander et al., 1999; Larocque et al., 2001).

CZ-II $(649-335 \mathrm{~cm})$ is associated with warm-temperature indicator taxa (Cladotanytarsus mancustype, Microtendipes pedellus-type, Dicrotendipes, Parakiefferiella bathophila-type, Chironomus plumosus-type) and taxa with a broad range of thermal 


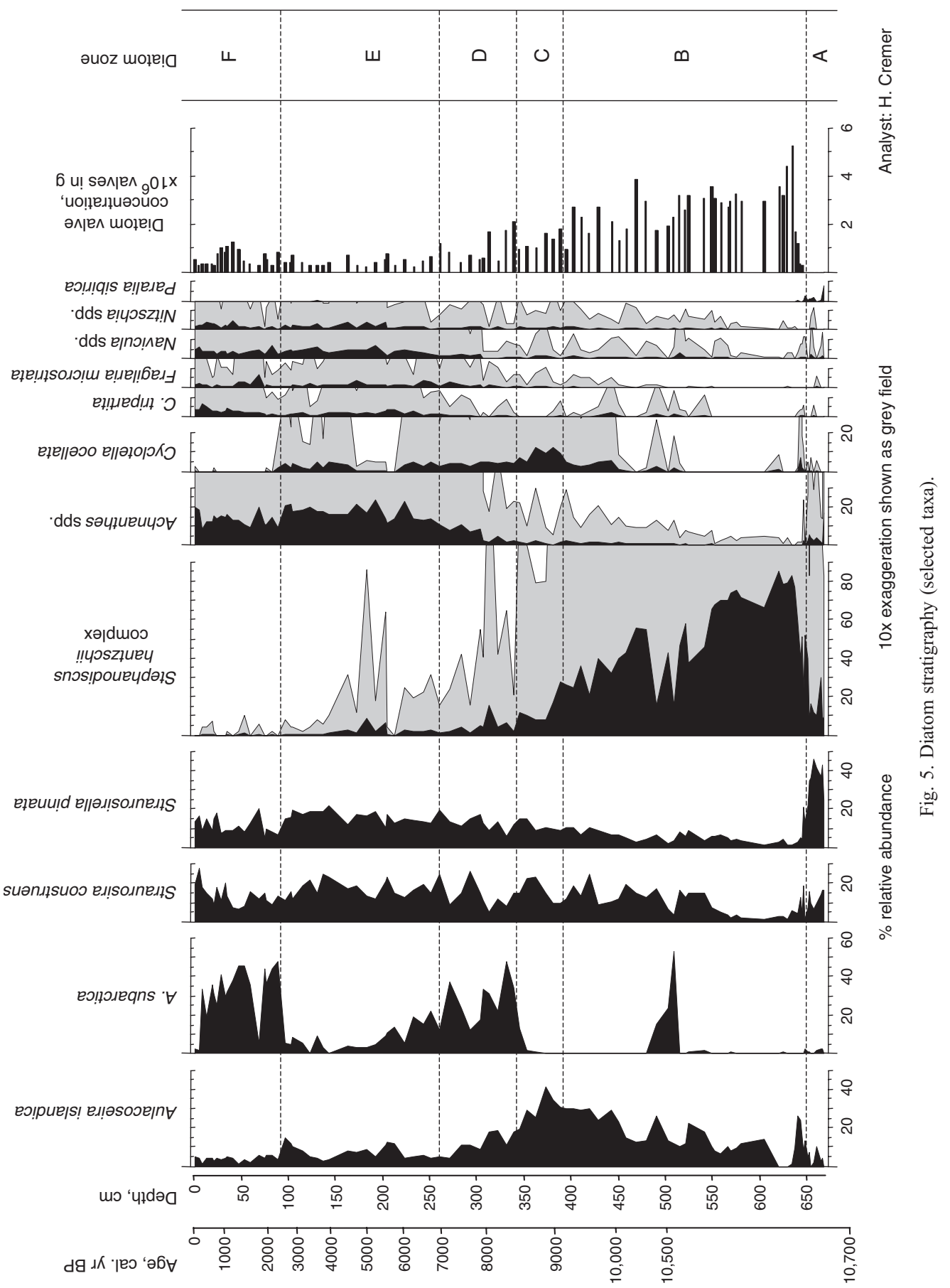




\begin{tabular}{l|l|l|l}
\hline \multirow{2}{\overline{N}}{} & $\overline{\bar{N}}$ & $\overline{\hat{N}}$ & $\bar{N}$ \\
\hline
\end{tabular}

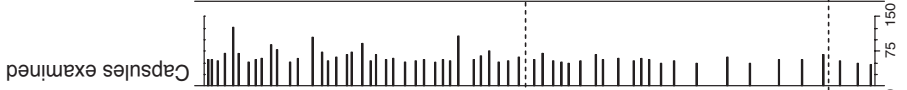

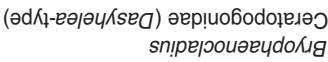

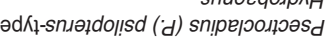
snسouод!บวоㄲ!ㅇ enбiqque еләэоикіоз səd!puәюоро?

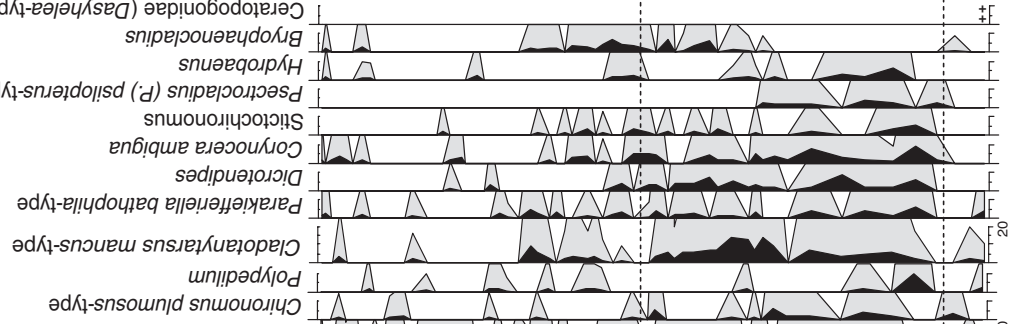

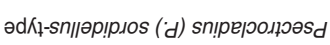

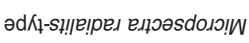

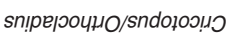

SnSAEXKue,

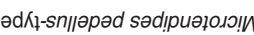

snsıęкuejesed

әdК-еи!эелог еппиәбљә

sn!pejoold

!̣ụnәиеұuә d ә $\mathrm{d}$ К

eшіәдоререле

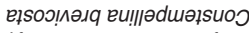

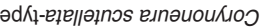

sndKuelold

snipepese d

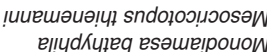

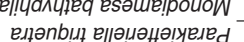

sәКчdoumilesed/sәКчdoumiา

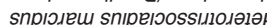

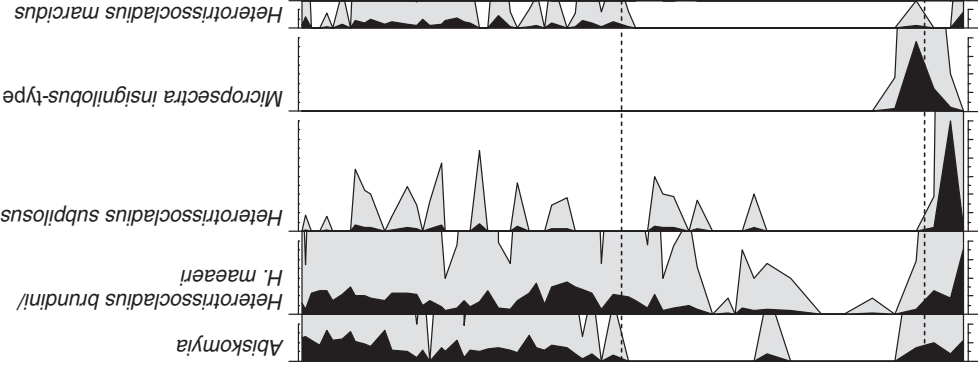

N
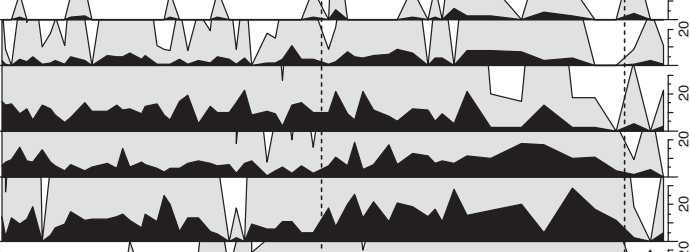

uо 'uाdə0 d曰 
tolerances (S. coracina-type, Cricotopus/Orthocladius, Paratanytarsus, Tanytarsus, Psectrocladius (P.) sordidellus-type, Corynocera ambigua) according to the different training sets (Lotter et al., 1997; Walker et al., 1997; Olander et al., 1999; Brooks and Birks, 2001; Larocque et al., 2001). In the lower part of the zone, the chironomid head-capsule concentration persists at low values (20-46 capsules $\mathrm{g}^{-1}$ ), whereas in the upper part of the zone it increases and reaches 67 151 capsules $\mathrm{g}^{-1}$.

In CZ-III $(335-0 \mathrm{~cm})$, all warm-temperature indicator taxa become minor components of the chironomid assemblages. The zone is characterized by a high abundance of taxa with a broad range of thermal tolerances (S. coracina-type, Cricotopus/Orthocladius, Tanytarsus, Paratanytarsus) and cold-temperature indicators (Micropsectra radialis-type, Abiskomyia, Heterotrissocladius brundini/H. maeaeri). Other cold-temperature indicator taxa such as Paracladius (Lotter et al., 1997; Walker et al., 1997), Constempellina brevicosta (Seppä et al., 2002), Mesocricotopus thienemanni (Walker et al., 1997; Olander et al., 1999), Paracladopelma (Lotter et al., 1997), and C. oliveri-type (Olander et al., 1999) become common. The chironomid head-capsule concentration gradually decreases up to 27-90 capsules $\mathrm{g}^{-1}$.

\section{Quantitative climate reconstructions}

\subsection{Pollen-based climate reconstructions}

The BMA method has been applied only to the pollen spectra from the upper $6.5 \mathrm{~m}$ of the core, because the lowest $0.5 \mathrm{~m}$ of the lake record contain high amounts of redeposited pollen and spores. Reconstructed mean July temperature $\left(T_{\mathrm{VII}}\right)$ and annual sum of the day temperatures above $5{ }^{\circ} \mathrm{C}$-base (the so-called sum of growing-degree-days with temperatures above $5{ }^{\circ} \mathrm{C}$, GDD5) show similar changes (Fig. 7a), suggesting summers warmer than present within the period 10,500-7500 cal. yr BP. Sharp climate oscillations towards cooler and dryer conditions are reconstructed from single pollen assemblages dated to ca 10,600 and ca 10,400 cal. yr BP, respectively. In both cases it corresponds to a decrease in Betula sect. Albae pollen percentages and in total pollen concentration. However, whether these short-term changes are primarily driven by climate or by other non-climatic factors (e.g. rapid sedimentation) is not clear. Thus, we avoid further interpretation of the reconstruction results at these levels. Significant coolings occurred ca. 7000, between 5500-3500 and after 1500 cal. yr BP. During the early Holocene climatic optimum, $T_{\mathrm{VII}}$ was likely 12-13 ${ }^{\circ} \mathrm{C}$, GDD5-400-600 ${ }^{\circ} \mathrm{C}$ day and annual precipitation $(P)-400-500 \mathrm{~mm}$. During the cold phases, $T_{\text {VII }}$ most probably fluctuated between 8 and $10{ }^{\circ} \mathrm{C}$, GDD5 between $100-300{ }^{\circ} \mathrm{C}$ day and $P$-between 300 and $400 \mathrm{~mm}$. The topmost pollen assemblage likely reflects warming of the twentieth century.

\subsection{Chironomid-inferred $T_{V I I}$ reconstructions}

The initial number of chironomid taxa recorded in the fossil assemblages (59 taxa) has been reduced up to 37 taxa after the taxonomic harmonization and the first screening. 28 fossil taxa from these 37 are present in the modern calibration data-set. Nine fossil taxa fit to the screening criteria, but those not present in the calibration set only comprise $0-15 \%$ of the total fossil assemblages in any sample. Six samples from the core between 177 and $67 \mathrm{~cm}$ (ca. 5100-1800 cal. yr BP) are an exception, as they contain higher proportions (18.3-23.1\%) of taxa which are absent in the calibration set. As derived from CCA with $T_{\mathrm{VII}}$ as the sole constraining predictor environmental variable, the squared residual distances of thirty samples (mainly between 650 and $270 \mathrm{~cm}$; Fig. 7b) are low and do not fall within the extreme $10 \%$ of the modern squared residual distances. Eighteen and twelve samples (mainly from the basal part and from upper $270 \mathrm{~cm}$ of the core, Fig. 7b) have 'poor' and 'very poor' fits, respectively, to the reconstructed $T_{\mathrm{VII}}$ values. That suggests that the chironomid-based reconstructions before 10,650 cal. yr BP and after 7000 cal. yr BP are relatively problematic. The reconstructions before 10,650 cal. yr BP and after 2500 cal. yr BP may be particularly problematic, as the samples from these intervals have only 'poor' or 'very poor' fits to $T_{\mathrm{VII}}$. $T_{\mathrm{VII}}$ reconstructed for the $7000-0$ cal. yr BP interval are probably overestimated due to the high proportion of cold-adapted taxa such as Paracladius, C. brevicosta and $M$. thienemanni, because these taxa are absent in the calibration set and, therefore, could not be used for the $T_{\mathrm{VII}}$ reconstructions. However, since smoothed temperature values may improve 'poor fit' 


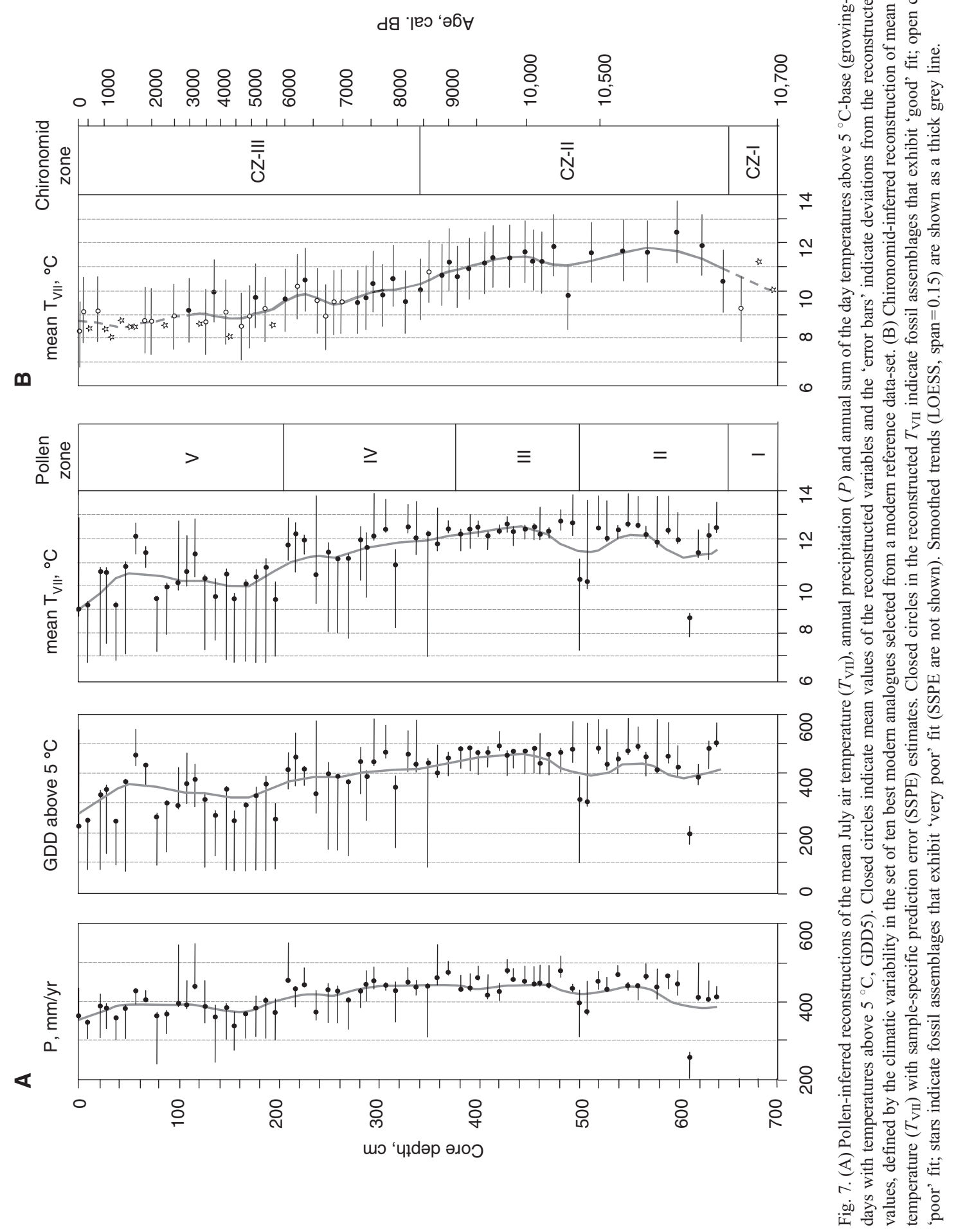


situations and provide a more reliable temperature estimate (Heiri et al., 2003), we use the smoothed trend of the $T_{\mathrm{VII}}$ reconstruction (Fig. $7 \mathrm{~b}$ ) as a basis for palaeoclimatic inferences.

The smoothed temperatures suggest that, shortly following the onset of lacustrine sedimentation at ca. $10,700-10,550$ cal. yr BP, $T_{\mathrm{VII}}$ increased rapidly from 10.0 to $11.8^{\circ} \mathrm{C}$. Later, during ca. $10,550-9400 \mathrm{cal}$. yr BP, there was a period of relatively high $T_{\mathrm{VII}}(11.0$ $\left.11.6{ }^{\circ} \mathrm{C}\right)$. Between ca. 9400 and $6800 \mathrm{cal}$. yr BP $T_{\mathrm{VII}}$ decreased gradually to $9.5^{\circ} \mathrm{C}$, followed by an increase to relatively high values $\left(9.8^{\circ} \mathrm{C}\right.$ at ca. $6300-6100 \mathrm{cal}$. yr BP). Later, $T_{\mathrm{VII}}$ decreased gradually to ca. 8.5-9.0 ${ }^{\circ} \mathrm{C}$, representing a period of minimum inferred temperatures during the lake history. In the uppermost sample of the core, the chironomid-inferred $T_{\mathrm{VII}}$ is 8.2 ${ }^{\circ} \mathrm{C}$ that is consistent with modern meteorological data $\left(T_{\mathrm{VII}}\right.$ ca. $\left.8.0^{\circ} \mathrm{C}\right)$ from the region.

\section{Discussion: palaeoenvironmental reconstructions}

The age of deposition of the lowest diamicton layer cannot be exactly determined. The bulk organic carbon ${ }^{14} \mathrm{C}$ ages of $39-34 \mathrm{kyr}$ BP only confirm the Middle Weichselian age of the bulk organic carbon in the diamicton. However, OSL dates from the samples collected from laminated fine sands in the kame sediments nearby the lake support an age of about 90 $\mathrm{ka}$ for the moraine deposits in the area (Henriksen et al., 2003). Glacial striae, erratics and form of the endmoraines show that the last ice-flow was from the Kara Sea. Geochemical and chronological analyses on the diamicton in the core also show that it may originate only from the Weichselian Barents-Kara Ice Sheet (Wischer et al., 2001). There is very few primary pollen and no diatoms or chironomids in the diamicton. Thus, the environmental conditions during the sedimentation of the lowest diamicton layer could not be reconstructed.

We suggest the following model for deposition. Dead ice blocks (remnants of the Early Weichselian Barents-Kara Ice Sheet) started to melt at the beginning of the Holocene, ca. 11,500-11,000 cal. yr BP forming the initial lake basin. Buried ice blocks in the present Quaternary sediments near the lake still remain and have been recovered during a reconnais- sance coring by Vorkuta Geological Survey in the area (Bol'shiyanov, pers. com.). Thus, the lowest diamicton layer, $1185-1035 \mathrm{~cm}$, is most likely reworked flow till of the Weichselian Barents-Kara Ice Sheet. The thin peat layer overlying the lowest diamicton suggests that the initial lake basin was probably well drained. Alternatively, melting of buried ice blocks in the Lake Lyadhej-To area was stopped or greatly slowed down ca. 10,900 cal. yr BP and processes of peat accumulation on the drained lake basin bottom began. Numerous Equisetum spores and rare Cyperaceae pollen in the peat layer may reflect a rather severe environment with denuded soils and pioneer vegetation around the lake basin during this time.

The second diamicton layer above the peat is also interpreted as reworked flow till sediments of the Barents-Kara Ice Sheet according to its composition, but it also contains rather numerous remains of terrestrial plants of younger ages (Table 1, Fig. 2), pointing to the higher input of younger non-till material in the upper diamicton layer. Thus, this layer is a mixture of reworked till and some younger, late Glacial and early Holocene sediments. There is too little primary pollen in the diamicton to reconstruct the environmental conditions during the sedimentation. The low TOC/N ratios in the upper $0.5 \mathrm{~m}$ of the diamicton point to input of minerogenous nitrogen, while $\delta{ }^{13} \mathrm{C}_{\text {org. }}$. values indicate the input of organic matter from terrestrial plants.

\subsection{Ca. 10,700-10,550 cal. yr BP}

All proxies indicate that sedimentation in the initial lake was with a high input of diamicton material containing reworked shells of Paleocene/Eocene taxon, Paralia sibirica, and redeposited Pinaceae pollen. The terrigenous input slowed at the end of this short episode. Pelagic bioproductivity in the lake was very low. The nearly complete absence of autochthonous planktic diatoms and low TOC content point to turbid and nutrient-poor lake conditions. A low abundance of chironomids characterizes the period. The dominance of lacustrine taxa (Abiskomyia, H. subpilosus, H. brundini/H. maeaeri,) in the chironomid assemblage confirms the onset of lacustrine conditions at ca. 10,700 cal. BP. The occurrence of Ceratopogonidae (Dasyhelea-type) remains at 694-696 cm may reflect swampy semi-aquatic habitats along the lake 
shoreline in this time, as aquatic and semi-aquatic species of Ceratopogonidae are common in transitional zones between aquatic and terrestrial habitats. This is particularly true for Dasyhelea (Szadziewski et al., 1997; Glukhova and Brodskaya, 1999). Coldtemperature chironomid taxa were rapidly replaced by warm-temperature ones at about 10,650 cal. BP. The chironomid-inferred reconstructions suggest that $T_{\text {VII }}$ increased rapidly to $11.8{ }^{\circ} \mathrm{C}$ between ca. 10,700 and 10,550 cal. BP (Fig. 7b). Summer temperatures were at least $2.5-3.0{ }^{\circ} \mathrm{C}$ higher than today at the end of this period. However, pollen-based reconstructions show the warmest climate conditions slightly later. This difference may be connected with some delay (ca. 50-150 cal. yr) of vegetation response to a rapidly changed climate, while chironomids assemblages probably changed in few years. Rare Cyperaceae, Poaceae and Betula sect. Nanae pollen suggest sparse, treeless vegetation around the lake. Large amounts of Equisetum spores, pollen of Cichoriaceae, Artemisia and the presence of Encalypta spores may also indicate disturbed and denuded soils in the catchment area.

\subsection{Ca. $10,550-8800$ cal. yr BP}

Biogeochemical proxies point to the lake period with maximum bioproduction (highest TOC, N, and $\mathrm{S}$ contents). Light $\delta^{13} \mathrm{C}_{\text {org }}$ values also point to the lacustrine (phytoplankton) source of the organic matter. The diatom, chironomid and pollen concentrations have their highest values. A distinct dominance of planktic diatoms reflects the most favourable conditions for diatoms ca. 10,500-8800 cal. yr BP (Fig. 5, see also Cremer et al., 2004). This interval is characterized by the longest growing season, the lowest lake-ice coverage and the highest diatom productivity during the lake history.

The highest abundances of littoral chironomid taxa (C. mancus-type, M. pedellus-type, Psectrocladius (P.) sordidellus-type, Dicrotendipes, Tanytarsus, Cricotopus/Orthocladius, C. ambigua) probably also reflect the high bioproductivity in the littoral zone of the lake in response to higher summer temperatures.

Betula (especially sect. Albae) pollen dominated the spectra. Influx of A. fruticosa pollen has a maximum in this period. Probably, birch forest with some shrub alder was growing in the lake catchment at this time. Pollen, macrofossil and insect records from the adjacent areas also reflect that tree birch dominated the vegetation in what is now treeless tundra northwest and north-east from the Lake Lyadhej-To (Surova et al., 1975; Veinbergs et al., 1995; Andreev et al., 1998, 2001; Koshkarova et al., 1999; Kaakinen and Eronen, 2000; Panova and Jankovska, 2000; Oksanen et al., 2001; Väliranta et al., 2001; Panova et al., 2003).

Pollen-based reconstructions of $T_{\mathrm{VII}}$ and GDD5 suggest warmest climate conditions during this period (Fig. 7a). The chironomid-inferred temperatures also show the highest value (Fig. 7b). This period is undoubtedly the warmest postglacial episode and marks the Holocene climatic optimum in the Arctic Eurasia (e.g. Velichko et al., 1997; MacDonald et al., 2000; Andreev et al., 2001, 2003, 2004).

\subsection{Ca. $8800-5500$ cal. yr BP}

This period is characterized by a gradual deterioration of environmental conditions in the lake and the lake catchment vicinity. Biogeochemical proxies show a decrease of TOC, $\mathrm{N}$ and $\mathrm{S}$ values, that together with a gradual increase of terrestrial $\delta^{13} \mathrm{C}_{\mathrm{org}}$ input point to a gradual decrease of bioproductivity in the lake. Lower concentrations of diatom valves suggest a lower diatom productivity in the lake (Fig. 5, Cremer et al., 2004). The abundance of Stephanodiscus decreased and $A$. islandica was partly replaced by $A$. subarctica, probably pointing to a slight tendency towards acidification of the lake. A. subarctica is an acidophilous diatom, indicating a $\mathrm{pH}$ below 7 (van Dam et al., 1994). The increased relative abundance of Achnanthes spp. and the contemporaneous decrease of planktonic diatoms ca. 7000 cal. yr BP (Fig. 5) might indicate an increased availability of benthic (e.g. epilithic, epipsammic, epipelic, epiphytic) habitats in the lake, possibly combined with an extended lake-ice cover in summers. This might have led to the relative enrichment of benthic diatoms in the sedimentary record. A longer lasting ice-cover during summers would have favoured the occurrence of benthic and aerophilic diatoms in a relatively narrow and shallow moat of the lake and in the lake's catchment (Smol, 1988). This is also evidenced by the distinctly reduced accumulation (total productivity) of diatom valves on the lake bottom (Fig. 5). 
The gradual replacement from warm-temperature chironomid taxa to cold-temperature ones as well as the decrease of total chironomid concentrations also reflect a gradual cooling. The chironomid-inferred temperatures suggest that the gradual decrease of $T_{\mathrm{VII}}$ lasted until ca. $6800 \mathrm{cal}$. BP, followed by a short period of the middle-Holocene warming with $T_{\text {VII }}$ at least $1^{\circ} \mathrm{C}$ higher than today.

An increase in Betula sect. Nanae, Cyperaceae, further increases of long-distance transported pollen (P. sylvestris, P. sibirica, Picea obovata, Corylus, Larix) and significantly reduced total pollen concentrations also point to a deterioration in climatic conditions. Probably, birch forests completely disappeared from the lake vicinity after 6000 cal. yr BP and shrub tundra with Betula nana and Salix started to dominate the vegetation. Pollen-based reconstructions suggest that climate conditions up to the end of this period were still relatively warm (Fig. 7a).

Palaeoenvironmental records from the adjacent areas also reflect similar vegetation changes and climate deterioration at about this time (Surova et al., 1975; Veinbergs et al., 1995; Andreev et al., 1998, 2001; Serebryanny et al., 1998; Koshkarova et al., 1999; Panova and Jankovska, 2000; Oksanen et al., 2001; Paus et al., 2003; Väliranta et al., 2001).

\subsection{Ca. 5500-2500 cal. yr BP}

Low TOC, $\mathrm{N}$ and $\mathrm{S}$ contents and the absence of authigenic carbonate in the sediments reflect low bioproductivity in the lake, pointing to rather cold environmental conditions in this period. The diatom record reflects the interval with the lowest accumulation of diatom valves (particularly planktonic diatoms) during the Holocene (Fig. 5), evidencing cooler summers with longer lasting lake-ice cover and low diatom productivity. The open-water habitats were probably restricted to a relatively narrow moat (Smol, 1988). Small benthic diatoms ( $S$. construens, S. pinnata, Achnanthes spp.) were favoured under such climate conditions (Fig. 5).

The relatively cold summers and poor trophic conditions in the lake during this period are also indicated by the occurrence of the cold-temperature chironomid taxa (Abiskomyia, Paracladius, H. subpilosus, M. radialis-type), which prefer ultra-oligotrophic conditions (Sæther, 1979). Modern chironomid assem- blages were established by the end of the period, with the disappearance of the warm-temperature indicator M. pedellus-type.

The vegetation in the region became similar to the modern one. Shrub (B. nana, Salix) and herb tundra dominated around the lake since ca. 5500 cal. yr BP. Palaeoenvironmental data from adjacent regions (Surova et al., 1975; Andreev et al., 2001; Oksanen et al., 2001; Kultti et al., 2003; Sarmaja-Korjonen et al., 2003) show similar changes occurring at the Atlantic-Subboreal boundary. Reconstructed $T_{\mathrm{VII}}$ and GDD5 suggest significant cooling between ca. 5500 and 3500 cal. yr BP, but with summers warmer than present ca. 3500-2500 cal. yr BP. During the cold phase, $T_{\mathrm{VII}}$ most probably was between $8-10{ }^{\circ} \mathrm{C}$, GDD5 was between $100-300{ }^{\circ} \mathrm{C}$, and annual precipitation was between 300 and $400 \mathrm{~mm}$.

\subsection{Ca. 2500 cal. yr BP-present day}

Generally, the bioproductivity in the lake was low during this time, but fluctuating TOC/TN ratios and slightly higher $\partial^{13} \mathrm{C}_{\text {org }}$ content reflect a higher terrestrial organic matter influx (Fig. 3). The distinctly increased abundance of $A$. subarctica (Fig. 5) points to ameliorated climatic conditions during this time. The lake was likely ice-free during summers leading to a significant growth of planktonic diatom taxa and higher accumulation of diatom valves on the lake bottom. The acidophilous nature of $A$. subarctica (van Dam et al., 1994) possibly also indicates a moderate decrease in lake-water $\mathrm{pH}$, which could have been caused by an increased influx of humic acids from the lake catchment. It also confirms a higher terrestrial nutrient supply. A similar shift from small fragilarioid diatom taxa to planktonic Aulacoseira ones was also described in a lake-sediment core from the western Taymyr Peninsula (Laing and Smol, 2003). Laing and Smol (2003) interpreted the peaks of Aulacoseira taxa in the core as indicators of warmer climatic conditions, which may have led to wind-induced mixing of the lake, higher input of humic substances and increased precipitation.

The pollen record reflects a dominance of the tundra vegetation, corresponding well with pollen data from adjacent regions (e.g. Andreev et al., 2001; Oksanen et al., 2001; Kultti et al., 2003). Pollen-based reconstructions of $T_{\mathrm{VII}}$ and GDD5 suggest a 
warming ca. 2000-1500 cal. yr BP and a cooling occurred after 1500 cal. yr BP.

The chironomid assemblages reflect a period of minimum $T_{\mathrm{VII}}$ during the lake history. However, chironomid inferences after 2500 cal. yr BP may not be reliable, as the fossil assemblages reveal a 'poor' or 'very poor' fit to $T_{\mathrm{VII}}$.

\section{Conclusions}

The radiocarbon-dated pollen, chironomid, diatom and biogeochemical records as well as results of quantitative climate reconstruction techniques show that Lake Lyadhej-To sediments are an excellent palaeoenvironmental archive since the beginning of the Holocene.

Dead ice blocks (remnants of the ice sheet) started to melt at the beginning of the Holocene, which formed the initial lake basin. A lower diamicton layer recovered in the lake is reworked flow till of the Early Weichselian Ice Sheet according to its composition. A second diamicton layer is a mixture of reworked till and younger, late Glacial/early Holocene sediments. Turbid and nutrient-poor lake conditions existed in the lake ca. 10,700-10,550 cal. yr BP. Summer temperatures were at least $2.5-3.0{ }^{\circ} \mathrm{C}$ higher than today. However, sparse and treeless vegetation dominated on the disturbed and denuded soils in the lake-catchment area.

The period ca. $10,500-8800$ cal. yr BP is noticeable for the lowest lake-ice coverage and the highest bioproductivity during the lake history. Birch forest with some shrub alder grew around the lake reflecting the warmest environmental conditions during the Holocene.

The period ca. $8800-5500$ cal. yr BP is characterized by a gradual deterioration of environmental conditions in the lake and its catchment. Birch forests disappeared from the lake catchment after 6000 cal. yr BP. Low shrub and herb tundra similar to modern vegetation dominated around the lake since ca. 5500 cal. yr BP. All proxies point to rather harsh environmental conditions, relatively short growing seasons and a longer lake-ice cover ca. 5500-2500 cal. yr BP.

The bioproductivity in the lake remained low after 2500 cal. yr BP, but terrestrial influx was higher.
Changes in diatom content indicate slightly warmer water temperatures and reduced ice cover on the lake.

\section{Acknowledgements}

The research of P. Tarasov in AWI, Potsdam was carried out during the tenure of an Alexander von Humboldt Fellowship. The chironomid study was supported by the DAAD grant awarded to B. Ilyashuk. We specially thank I. Larocque for allowing the use of the chironomid-temperature calibration data-set developed in north Sweden. We would also like to thank Mona Henriksen, who made critical, but helpful comments on the first version of the manuscript, and John Smol and an anonymous reviewer for their helpful comments for the second version of the manuscript.

\section{References}

Andreev, A.A., Klimanov, V.A., 2000. Quantitative Holocene climatic reconstruction from Arctic Russia. Journal of Paleolimnology 24, 81-91.

Andreev, A.A., Tarasov, P.E., Romanenko, F.A., Sulerzhitsky, L.D., Terekhov, K.I., 1998. Vegetation on the west coast of Baidaratskaya Guba during the late Pleistocene and Holocene. Stratigraphy and Geological Correlation 6, 520-525.

Andreev, A.A., Manley, W.F., Ingólfsson, Ó., Forman, S.L., 2001. Environmental changes on Yugorsky Peninsula, Kara Sea, Russia, during the last 12,800 radiocarbon years. Global and Planetary Change 31, 253-262.

Andreev, A.A., Tarasov, P.E., Siegert, Ch., Ebel, T., Klimanov, V.A., Bobrov, A.A., Melles, M., Dereviagin, A.Yu., Hubberten, H.-W., 2003. Vegetation and climate changes on the northern Taymyr, Russia during the upper Pleistocene and Holocene reconstructed from pollen records. Boreas 32, 484-505.

Andreev, A.A., Tarasov, P.E., Schwamborn, G., Ilyashuk, B.P., Ilyashuk, E.A., Bobrov, A.A., Klimanov, V.A., Rachold, V., Hubberten, H.-W., 2004. Holocene palaeoenvironmental records from Nikolay Lake, Lena river Delta, Arctic Russia. Palaeogeography, Palaeoclimatology, Palaeoecology 209, 197-217.

Ariztegui, D., McKenzie, J.A., 1995. Temperature-dependent carbon-isotope fractionation of organic matter: a potential paleoclimatic indicator in Holocene lacustrine sequences. In: Frenzel, B. (Ed.), Problems of Stable Isotopes in Tree-Rings, Lake Sediments and Peat-Bogs as Climatic Evidence for the Holocene. Gustav Fischer Verlag, Stuttgart, pp. 7-28.

Astakhov, V.I., Svendsen, J.I., Matiouchkov, A., Mangerud, J., Maslenikova, O., Tveranger, J., 1999. Marginal formations of the last Kara and Barents ice shelves in northern European Russia. Boreas 28, 23-45. 
Atlas Arktiki, 1985. Central Administration for Geodesy and Cartography of the Ministerial Council of the USSR. Moscow, (In Russian).

Battarbee, R.W., 1973. A new method for estimation of absolute microfossil numbers, with reference especially to diatoms. Limnology and Oceanography 18, 647-653.

Berglund, B.E., Ralska-Jasiveczowa, M., 1986. Pollen analysis and pollen diagrams. In: Berglund, B.E. (Ed.), Handbook of Holocene Palaeoecology and Palaeohydrology. Interscience, New York, pp. 455-484.

Bigler, C., Larocque, I., Peglar, S.M., Birks, H.J.B., Hall, R.I., 2002. Quantitative multiproxy assessment of long-term patterns of Holocene environmental change from a small lake near Abisko, northern Sweden. The Holocene 12, 481-496.

Birks, H.J.B., 1995. Quantitative palaeoenvironmental reconstructions. In: Maddy, D., Brew, J.S. (Eds.), Statistical Modelling of Quaternary Science Data. Quaternary Research Association XII, Cambridge, pp. 161-254.

Birks, H.J.B., 1998. Numerical tools in paleolimnology-progress, potentialities, and problems. Journal of Paleolimnology 20, $307-332$.

Birks, H.J.B., Line, J.M., Juggins, S., Stevenson, A.C., ter Braak, C.J.F., 1990. Diatoms and $\mathrm{pH}$ reconstruction. Philosophical Transactions of the Royal Society London. B 327, 263-278.

Brooks, S.J., Birks, H.J.B., 2000. Chironomid-inferred late-glacial and early-Holocene mean July air temperature for Kråkenes Lake, western Norway. Journal of Paleolimnology 23, 77-89.

Brooks, S.J., Birks, H.J.B., 2001. Chironomid-inferred air temperatures from late-glacial and Holocene sites in north-west Europe: progress and problems. Quaternary Science Reviews 20, $1723-1741$.

Bolikhovskaya, N.S., Bolikhovskii, V.F., 1994. Landscape and climate conditions of cryogenesis during late Pleistocene on the Yamal Peninsula. Deponent VINITI N3082-B94, 40 pp. (In Russian).

Bolikhovskaya, N.S., Bolikhovskii, V.F., Klimanov, V.A., 1988. Climatic and cryogenic factors of peatlands development on northeast of European part of USSR during the Holocene. In: Khotinskiy, N.A., Klimanov, V.A. (Eds.), Paleoklimaty Golotsena Evropeiskoi Territorii SSSR. Institute of Geography of Academy of Sciences of USSR, Moscow, pp. 36-44. (In Russian).

Cleveland, W.S., Grosse, E., Shyu, W.M., 1993. Local regression models. In: Chambers, J.M., Hastie, T.J. (Eds.), Statistical Models. Chapman and Hall, London, pp. 309-376.

Cremer, H., Wagner, B., Melles, M., Hubberten, H.-W., 2001. The postglacial environmental development of Raffles Sø, East Greenland: inferences from a 10,000 year diatom record. Journal of Paleolimnology 26, 67-87.

Cremer, H., Andreev, A., Hubberten, H.-W., Wischer, F., 2004. Paleolimnological reconstructions of Holocene environments and climate from Lake Lyadhej-To, Ural Mountains, Northern Russia. Arctic, Antarctic, and Alpine Research 36, $147-155$.

Edwards, M.E., Anderson, P.M., Brubaker, L.B., Ager, T.A., Andreev, A.A., Bigelow, N.H., Cwynar, L.C., Eisner, W.R., Harrison, S.P., Hu, F-S., Jolly, D., Lozhkin, A.V., MacDonald,
G.M., Mock, C.J., Ritchie, J.C., Sher, A.V., Spear, R.W., Williams, J.W., Yu, G., 2000. Pollen-based biomes for Beringia $18,000,6000$ and $0{ }^{14} \mathrm{C}$ yr BP. Journal of Biogeography 27, $521-555$.

Glukhova, V.M., Brodskaya., N.K., 1999. Ceratopogonidae. Biting midges. In: Tsalolikhin. S.J. (Ed.) Key to Freshwater Invertebrates of Russia and Adjacent lands. vol. 4. Higher Insects. Diptera, Zoological Institute RAS, Petersburg, pp. 183-209, 580-669. In Russian.

Grimm, E., 1991. TILIA and TILIAGRAPH. Illinois State Museum, Springfield, Illinois.

Guiot, J., 1990. Methodology of palaeoclimatic reconstruction from pollen in France. Palaeogeography, Palaeoclimatology, Palaeoecology 80, 49-69.

Guiot, J., Goeury, C., 1996. PPPBASE, a software for statistical analysis of paleoecological and paleoclimatological data. Dendrochronologia 14, 295-300.

Gundelwein, A., 1998. Eigenschaften und Umsetzung organischer Substanz in nordsibirischen Permafrostböden. Hamburger Bodenkundliche Arbeiten, 39.

Heiri, O., Lotter, A.F., 2001. Effect of low counts sums on quantitative environmental reconstructions: an example using subfossil chironomids. Journal of Paleolimnology 26, 343-350.

Heiri, O., Lotter, A.F., Hausmann, S., Kienast, F., 2003. A chironomid-based Holocene summer air temperature reconstruction from the Swiss Alps. The Holocene 13, 477-484.

Heiri O., T. Ekrem, Willassen E., 2004. Larval head capsules of European Micropsectra, Paratanytarsus and Tanytarsus (Diptera: Chironomidae: Tanytarsini). Version 1.0. (http://www.bio.uu.nl/ $\sim$ palaeo/Chironomids/Tanytarsini/intro.htm).

Henriksen, M., Mangerud, J., Matiouchkov, A., Paus, A., Svendsen, J.I., 2003. Lake stratigraphy implies an $80,000 \mathrm{yr}$ delayed melting of buried dead ice in northern Russia. Journal of Quaternary Science 18, 663-769.

Hermichen, W.-D., Gierlichs, A., Wischer, F., Bolshiyanov, D., 2000. Eurasian ice sheets: German-Russian expedition Polar Ural 99. Berichte zur Polarforschung 354, 271-303.

Hofmann, W., 1971. Zur taxonomie und palökologie subfossiler chironomiden (Dipt.) in seesedimenten. Archiv für Hydrobiologie Beihefte Ergebnisse der Limnologie 6, 1-50.

Hubberten, H.-W., Andreev, A.A., Astakhov, V.I., Demidov, I., Dowdeswell, J.A., Henriksen, M., Hjort, Ch., Houmark-Nielsen, M., Jakobsson, M., Kuzmina, S., Larsen, E., Lunkka, J.P., Lyså, A., Mangerud, J., Möller, P., Saarnisto, M., Schirrmeister, L., Sher, A.V., Siegert, Ch., Siegert, M.J., Svendsen, J.I., 2004. The periglacial environment and climate in Northern Eurasia during the Last Glaciation (LGM). Quaternary Science Reviews 23, $1333-1357$.

Ilyashuk, E.A., Ilyashuk, B.P., Hammarlund, D., Larocque, I., in press. Holocene climatic and environmental changes inferred from midge (Diptera: Chironomidae, Chaoboridae, Ceratopogonidae) records at Lake Berkut, southern Kola Peninsula, Russia. The Holocene 15.

Kaakinen, A., Eronen, M., 2000. Holocene pollen stratigraphy indicating climatic and tree-line changes derived from a peat section at Ortino, in the Pechora lowland, northern Russia. The Holocene 10, 611-620. 
Korhola, A., Olander, H., Blom, T., 2000. Cladoceran and chironomid assemblages as quantitative indicators of water depth in subarctic Fennoscandian lakes. Journal of Paleolimnology 24, 43-54.

Koshkarova, V.L., Karpenko, L.V., Orlova, L.A., 1999. The Holocene dynamics of vegetation and the upper forest limit in the Polar Urals. Russian Journal of Ecology 30, 102-106.

Krammer, K., Lange-Bertalot, H., 1991. Bacillariophyceae 4. Teil: achnabntaceae. In: Ettl, H., Gärtner, G., Gerloff, J., Heynig, H., Mollenhauer, D. (Eds.), Süßwasserflora von Mitteleuropa, vol. 2/4. Gustav Fischer Verlag, Heidelberg.

Krammer, K., Lange-Bertalot, H., 1999. Bacillariophyceae 1. Teil: naviculaceae. In: Gerloff, H., Heynig, J., Mollenhauer, H. (Eds.), Süßwasserflora von Mitteleuropa, vol. 2/1. Gustav Fischer Verlag, Heidelberg.

Krammer, K., Lange-Bertalot, H., 1999. Bacillariophyceae 2. Teil: bacillariaceae, epithemiaceae, surirellaceae. In: Ettl, H., Gerloff, J., Heynig, H., Mollenhauer, D. (Eds.), Süßwasserflora von Mitteleuropa, vol. 2/2. Gustav Fischer Verlag, Heidelberg.

Krammer, K., Lange-Bertalot, H., 2000. Bacillariophyceae 3. Teil: centrales, fragilariaceae, eunotiaceae. In: Ettl, H., Gerloff, J., Heynig, H., Mollenhauer, D. (Eds.), Süßwasserflora von Mitteleuropa, vol. 2/3. Gustav Fischer Verlag, Heidelberg.

Kultti, S., Väliranta, M., Sarmaja-Korjonen, K., Solovieva, N., Virtanen, T., Kauppila, T., Eronen, M., 2003. Palaeoecological evidence of changes in vegetation and climate during the Holocene in the pre-Polar Urals, northeast European Russia. Journal of Quaternary Science 18, 503-520.

Kupriyanova, L.A., Aleshina, L.A., 1972. Pollen and spores of plants from the European part of the USSR. Nauka, Leningrad. (In Russian).

Kupriyanova, L.A., Aleshina, L.A., 1978. Pollen of dicotyledonian plants from the European part of the USSR. Nauka, Leningrad. (In Russian).

Laing, T.E., Smol, J.P., 2003. Late Holocene environmental changes inferred from diatoms in a lake on the western Taymyr Peninsula, northern Russia. Journal of Paleolimnology 30, 231-247.

Larocque, I., 2001. How many chironomid head capsules are enough? A statistical approach to determine sample size for palaeoclimatic reconstructions. Palaeogeography, Palaeoclimatology, Palaeoecology 172, 133-142.

Larocque, I., Hall, R.I., Grahn, E., 2001. Chironomids as indicators of climate change: a 100-lake training set from a subarctic region of northern Sweden (Lapland). Journal of Paleolimnology $26,307-322$.

Leemans, R., Cramer, W., 1991. The IIASA Database for Monthly Values of Temperature, Precipitation and Cloudiness of Global Terrestrial Grid RR-91-18. International Institute for Applied Systems Analysis, Laxenburg.

Lotter, A.F., Birks, H.J.B., Hofmann, W., Marchetto, A., 1997. Modern diatom, cladocera, chironomid, and chrysophyte cyst assemblages as quantitative indicators for the reconstruction of past environmental conditions in the Alps: I. Climate. Journal of Paleolimnology 18, 395-420.

Lozhkin, A.V., Anderson, P.M., Vartanyan, S.L., Brown, T.A., Belaya, B.V., Kotov, A.N., 2001. Late Quaternary paleoenvir- onments and modern pollen data from Wrangel Island (Northern Chukotka). Quaternary Science Reviews 20, 217-233.

MacDonald, G.M., Kremenetski, C.V., Velichko, A.A., Cwynar, L.C., Riding, R.T., Goleva, A.A., Andreev, A.A., Borisova, O.K., Edwards, T.W.D., Hammarlund, D., Szeicz, J.M., Forman, S., Gataullin, V.I., 2000. Holocene treeline history and climate change across Northern Eurasia. Quaternary Research 53, 302-311.

Makarchenko, E.A., Makarchenko, M.A., 1999. Chironomidae. Non-biting midges. In: Tsalolikhin, S.J. (Ed.), Key to Freshwater Invertebrates of Russia and Adjacent Lands. Volume 4. Higher Insects. Diptera. Zoological Institute RAS, Petersburg, pp. 210-95, 670-857 (in Russian).

Mangerud, J., Astakhov, V.I., Murray, A., Svendsen, J.I., 2001. The chronology of a large ice-dammed lake and the Barents-Kara ice sheet advances, northern Russia. Global and Planetary Change 31, 321-336.

Mangerud, J., Astakhov, V.I., Svendsen, J.I., 2002. The extend of the Barents-Kara sea ice sheet during the last glacial maximum. Quaternary Science Reviews 21, 111-119.

Melles, M., Wand, U., Hermichen, W.-D., Bergemann, B., Bolshiyanov, D., Khrutsky, S.F., 1994. The expedition Norilsk/Taymyr 1993 of the AWI Research Unit Potsdam. Berichte zur Polarforschung 148, 3-28.

Nikiforova, L.D., 1980. Some questions of environment changes and peat accumulation on the north of Russian plain. In: Elina, G.N. (Ed.), Bolota Evropeiskogo Severa SSSR. Karelian Scientific Center, Petrozavodsk, pp. 155-177 (in Russian).

Nikiforova, L.D., 1982. Holocene dynamics of landscape zones in northeast of European part of USSR. In: Velichko, A.A. (Ed.), Razvitie Prirody Territorii SSSR v Pozdnem Pleistotsene i Golotsene. Nauka, Moscow, pp. 154-162 (in Russian).

Oksanen, P.O., Kuhry, P., Alexeeva, R.N., 2001. Holocene development of the Rogovaya river peat plateau European Russian Arctic. The Holocene 11, 25-40.

Olander, H., Birks, H.J.B., Korhola, A., Blom, T., 1999. An expanded calibration model for inferring lake water and air temperatures from fossil chironomid assemblages in northern Fennoscandia. The Holocene 9, 279-294.

Pankratova, V.Ya., 1970. Larvae and pupae of non-biting midges of the subfamily Orthocladiinae (Diptera, Chironomidae-Tendipedidae) of the USSR fauna. Opredeliteli Fauny SSSR 102 Nauka, Leningrad (in Russian).

Pankratova, V.Ya., 1983. Larvae and pupae of non-biting midges of the subfamily Chironominae (Diptera, Chironomidae-Tendipedidae) of the USSR fauna. Opredeliteli Fauny SSSR 134 Nauka, Leningrad (in Russian).

Panova, N.K., Jankovska, V., 2000. Dynamics of vegetation on timberline of the Polar Urals during the Holocene. In: Kuznetsov, O.L., Elina, G.A., Grabovik, S.I. (Eds.), Dynamics of Bog Ecosystems in Northern Eurasia During the Holocene. Karelian Scientific Center, Petrozavodsk, pp. 1115 (in Russian).

Panova, N.K., Jankovska, V., Korona, O.M., Zinov'ev, E.V., 2003. The Holocene dynamics of vegetation and ecological conditions of the Polar Urals. Russian Journal of Ecology 34, 219-230. 
Paus, A., Svendsen, J.I., Matiouchkov, A., 2003. Late Weichselian (Valdaian) and Holocene vegetation and environmental history of the northern Timan ridge European Arctic Russia. Quaternary Science Reviews 22, 2285-2302.

Pisaric, M.F.J., MacDonald, G.M., Cwynar, L.C, Velichko, A.A., 2001. Modern pollen and conifer stomates from north-central Siberian lake sediments: their use in interpreting late quaternary fossil assemblages. Arctic, Antarctic, and Alpine Research 33, $19-27$.

Punt, W., Blackmore, S. (Eds.), 1995. The Northwest European Pollen Flora, vol. 7. Elsevier, Amsterdam.

Punt, W., Blackmore, S., Clarke, G.C.S. (Eds.), 1988. The Northwest European Pollen Flora, vol. 5. Elsevier, Amsterdam.

Punt, W., Blackmore, S., Hoen, P.P. (Eds.), 1995. The Northwest European Pollen Flora, vol. 6. Elsevier, Amsterdam.

Punt, W., Blackmore, S., Hoen, P.P., Stafford, J.P. (Eds.), 2003. The Northwest European Pollen Flora, vol. 8. Elsevier, Amsterdam.

Quinlan, R., Smol, J.P., 2001. Setting minimum head capsule abundance and taxa deletion criteria in chironomid-based inference models. Journal of Paleolimnology 26, 327-342.

Reille, M.,1992. Pollen et spores d' Europe et d' Afrique du nord. Editions du Laboratoire de Botanique Historique et Palynologie Marseille.

Reille, M. 1995. Pollen et spores d'Europe et d'Afrique du nord. Supplement 1. Editions du Laboratoire de Botanique Historique et Palynologie Marseille.

Reille, M. 1998. Pollen et spores d'Europe et d'Afrique du nord. Supplement 2. Editions du Laboratoire de Botanique Historique et Palynologie Marseille.

Sarmaja-Korjonen, K., Kultti, S., Solovieva, N., Väliranta, M., 2003. Mid-Holocene palaeoclimatic and palaeohydrological conditions in north-eastern European Russia: a multiproxy study of lake Vankavad. Journal of Paleolimnology 30, $415-426$.

Sæther, O.A., 1975. Neoarctic and palaearctic heterotrissocladius (Diptera: chironomidae). Bulletin of the Fisheries Research Board of Canada 193, 1-67.

Sæther, O.A., 1979. Chironomid communities as water quality indicators. Holarctic Ecology 2, 65-74.

Seppä, H., Nyman, M., Korhola, A., Weckström, J., 2002. Changes of treeline and alpine vegetation in relation to post-glacial climate dynamics in northern Fennoscandia based on pollen and chironomid records. Journal Quaternary Science 17, 287-301.

Serebryanny, L., Andreev, A., Malyasova, E., Tarasov, P., Romanenko, F., 1998. Late Glacial and early Holocene environment in the Russian Arctic. The Holocene 8, 323-330.

Smol, J.P., 1988. Paleoclimate proxy data from freshwater arctic diatoms. Verhandlungen der Internationalen Vereinigung der Limnologie 23, 837-844.

Solovieva, N., Tarasov, P., MacDonald, G. in press Quantitative reconstruction of Holocene climate from Chuna Lake pollen record, Kola Peninsula, north-west Russia. The Holocene 15(1).

Surova, T.G., 1967. About the development of vegetation on the Polar Urals during the Holocene. Vestnik Moskovskogo Universiteta. Biologiya-Pochvovedenie 2, 66-74 (in Russian).

Surova, T.G., Troitsky, L.S., Punning, Ya.-M., 1975. Palaeogeography and absolute chronology of the Holocene on Polar Urals.
Eesti NSV Teaduste Akademia Tiometised. Keemia, Geoloogia 24 (2), 152-159 (in Russian).

Stuiver, M., Reimer, P.J., Bard, E., Beck, J.W., Burr, G.S., Hughen, K.A., Cromer, B., McCormic, G., van der Plicht, J., Spurk, M., 1998. INTCAL 98 radiocarbon age calibration, 24,000-0 cal BP. Radiocarbon 40, 1041-1083.

Szadziewski, R., Krzywiñski, J., Giłka, W., 1997. Diptera Ceratopogonidae, biting midges. In: Nilsson, A. (Ed.), The Aquatic Insects of North Europe, vol. 2. Apollo Books, Stenstrup, pp. $243-263$.

Tarasov, P.E., Webb III, T., Andreev, A.A., Afanas'eva, N.B., Berezina, N.A., Bezusko, L.G., Blyakharchuk, T.A., Bolikhovskaya, N.S., Cheddadi, R., Chernavskaya, M.M., Chernova, G.M., Dorofeyuk, N.I., Dirksen, V.G., Elina, G.A., Filimonova, L.V., Glebov, F.Z., Guiot, J., Gunova, V.S., Harrison, S.P., Jolly, D., Khomutova, V.I., Kvavadze, E.V., Osipova, I.M., Panova, N.K., Prentice, I.C., Saarse, L., Sevastyanov, D.V., Volkova, V.S., Zernitskaya, V.P., 1998. Present-day and mid-Holocene biomes reconstructed from pollen and plant macrofossil data from the former Soviet Union and Mongolia. Journal of Biogeography 25, 1029-1053.

Tarasov, P.E., Andreev, A.A., Hubberten, H.-W., 2002. Quantitative climate reconstruction based on pollen data from Russian Arctic. Abstracts of European Geophysical XXVII General Assembly. Nice, France. 21-26 April.

ter Braak, C.J.F., Juggins, S., 1993. Weighted averaging partial least squares regression (WA-PLS): an improved method for reconstructing environmental variables from species assemblages. Hydrobiologia 269/270, 485-502.

ter Braak, C.J.F., Šmilauer, P., 1998. Canoco for Windows: Software for Canonical Community Ordination (version 4). Microcomputer Power, Ithaca, NY.

Väliranta, M., Kaakinen, A., Kuhry, P., 2001. Holocene climate and landscape evolution east of Pechora Delta, East-European Arctic. Quaternary Research 59, 335-344.

van Dam, H., Mertens, A., Sinkeldam, J., 1994. A coded checklist and ecological indicator values of freshwater diatoms from The Netherlands. Netherlands Journal of Aquatic Ecology 28, $117-133$.

Veinbergs, I.G., Stelle, V.Ya., Savvaitov, A.I., Yakubovskaya, I.Ya., 1995. Late Quaternary history of Pechora Sea coast. In: Svitoch, A.A. (Ed.), Korrelazii paleogeographicheskikh sobytiy: materik-shelf-okean. Materialy konferenztsii, Moskva, MGU, 26-28 maya 1992. Moscow State University, Moscow, pp. 106-112 (in Russian).

Velichko, A.A., Andreev, A.A., Klimanov, V.A., 1997. The dynamics of climate and vegetation in the tundra and forest zone during the late Glacial and Holocene. Quaternary International 41/42, 71-96.

Walker, I.R., 2001. Midges: Chironomidae and related Diptera. In: Smol, J.P., Birks, H.J.B., Last, W.M. (Eds.), Tracking Environmental Change Using Lake Sediments. vol. 4, Zoological Indicators. Kluwer Academic Publisher, Dordrecht, pp. 43-66.

Walker, I.R., Levesque, A.J., Cwynar, L.C., Lotter, A.F., 1997. An expanded surface-water paleotemperature inference model for use with fossil midges from eastern Canada. Journal of Paleolimnology 18, 165-178. 
Chironomidae of the Holarctic region. In: Wiederholm, T. (Ed.), Keys and diagnoses: Part 1. Larvae, Entomologica Scandinavica. Supplement, vol. 19.

Wischer, F., Andreev, A., Hermichen, W.-D., Hubberten, H.-W., 2001. The late-Quaternary environmental history of the western foreland of the Polar Urals inferred from lake sediment studies. EUG XI, 8-12 April, Programme and Abstract Volume. Strasbourg: European Union of Geosciences, p. 217. 